Research paper

\title{
Palaeoenvironmental conditions for the preservation of organic matter during the late Hauterivian in the Neuquén Basin (Western Argentina)
}

\author{
Julieta Omarini $^{\mathrm{a}, \mathrm{b}, *}$, Marina Lescano ${ }^{\mathrm{c}}$, Andrea Lorena Odino-Barreto ${ }^{\mathrm{d}}$, Débora Campetella ${ }^{\mathrm{a}, \mathrm{b}}$, \\ Maísa Tunik ${ }^{\mathrm{a}, \mathrm{b}}$, Grony Garbán ${ }^{\mathrm{e}, \mathrm{f}}$, Fabián Brea ${ }^{\mathrm{g}}$, Georgina Erra ${ }^{\mathrm{g}}$, Beatriz Aguirre-Urreta ${ }^{\mathrm{c}}$, \\ Mathieu Martinez
}

\author{
a Universidad Nacional de Río Negro, CONICET, Instituto de Investigación en Paleobiología y Geología, General Roca, Río Negro, Argentina \\ ${ }^{\mathrm{b}}$ IIPG, CONICET. Av. J. A. Roca, 1242, General Roca, Río Negro, Argentina \\ ${ }^{\mathrm{c}}$ Instituto de Estudios Andinos Don Pablo Groeber (CONICET-UBA), Buenos Aires, Argentina \\ ${ }^{\mathrm{d}}$ Centro de Investigaciones Geológicas (CONICET-UNLP), La Plata, Buenos Aires, Argentina \\ ${ }^{\mathrm{e}}$ DTP Laboratorios SRL, Cordarco 1136/38, Buenos Aires, Argentina \\ ${ }^{\mathrm{f}}$ Instituto de Ciencias de la Tierra, Facultad de Ciencias, Universidad Central de Venezuela, Caracas, Venezuela \\ ${ }^{\mathrm{g}}$ Y-TEC (YPF Tecnología), Av. del Petróleo Argentino, 900-1198, Berisso, Buenos Aires, Argentina \\ ${ }^{\mathrm{h}}$ Univ Rennes, CNRS, Géosciences Rennes - UMR 6118, F-35000 Rennes, France
}

\section{A R T I C L E I N F O}

\section{Keywords:}

Organic geochemistry

Total Organic Carbon (TOC)

Palaeoproductivity

Palaeoceanographic changes

Agua de la Mula Member

Agrio Formation

Cretaceous

\begin{abstract}
A B S T R A C T
The Agua de la Mula Member of the Agrio Formation, comprises marine deposits accumulated in a mixed carbonate-siliciclastic outer ramp during the late Hauterivian. An innovative multi-proxy study that includes sedimentological, geochemical and paleobiological data from the El Portón section were combined in order to constrain the environmental context.

Two major sedimentary cycles have been recognised (TST-HST) reflecting the position of both distal and proximal sediments within the depositional system. The distal outer ramp deposits (FA1) are predominantly characterised by carbonate-bearing mudstones, with TOC content up to $4.43 \mathrm{wt} \%$ TOC (average $1.62 \mathrm{wt} \%$ ) and Type II marine-derived amorphous organic matter. The high TOC could be reflecting enhanced bioproductivity during periods of decreased salinity as mirrored by peaks of Micrantholithus, and reduced dilution by siliciclastic material in a distal setting. Conversely, the proximal outer ramp succession (FA2) shows a higher siliciclastic pattern, along with the terrestrial organic matter signal (Type II-III kerogen) and TOC content around 1 wt $\%$ (average $1.05 \mathrm{wt} \%$ ). In this interval primary production is associated with more stable conditions and stratified water, as reflected in peaks of Nannoconus. These conditions allowed a greater diversity and high abundances of calcareous nannofossil assemblages.
\end{abstract}

\section{Introduction}

The study of shales rocks has captured widespread interest across the E\&P industry. In recent years, petroleum scientists have focused on shale oil and gas reservoirs since they have become important targets for unconventional hydrocarbon recovery a decade ago. In the Neuquén Basin, the studies are mainly related to the Vaca Muerta Formation being recognised as the most prolific hydrocarbon generating rock in the basin (Urien and Zambrano, 1994; Villar et al., 1998, 2005; Uliana et al., 1999; Fantín and González, 2014, Kietzmann et al., 2014a; González Tomassini et al., 2015). In the particular case of the Agrio Formation the organic geochemistry studies pre-dated the shale revolution. Different authors have interpreted the stratigraphy, the geochemical properties and the thermal evolution of this unit (Uliana and Legarreta, 1993; Urien and Zambrano, 1994; Cruz et al., 1996, 1998; Kozlowski et al., 1998; Uliana et al., 1999). Recent works have reviewed and compiled all these data and presented an overview of its geochemistry, hydrocarbon generation patterns and palaeoenvironment (Legarreta et al., 2005; Tyson et al., 2005; Legarreta and Villar, 2012). However, there are still few publications with a complete and integrated sedimentological, organic geochemical and micropaleontological approach of this potential shale play (Guler et al., 2013; Comerio et al., 2017a, 2017b; Moore, 2018; Moore et al., 2020).

This work presents a study of the Agua de la Mula Member of the Agrio Formation at the El Portón locality, offering the possibility of a high-resolution investigation due to a continuous sedimentation with a

\footnotetext{
* Corresponding author. Universidad Nacional de Río Negro, CONICET, Instituto de Investigación en Paleobiología y Geología, General Roca, Río Negro, Argentina.

E-mail address: jomarini@unrn.edu.ar (J. Omarini).
} 
good bioestratigraphical control, in order to better define the palaeoceanographic and the palaeoproductivity changes in an hemipelagic basin.

Reconstruction of changes requires the use of proxies, such as sedimentologic and stratigraphical data, organic matter type and content, mineralogic composition and calcareous nannofossils. The delineation of depositional sequences and systems tracts are based on the recognition of numerous factors such as unconformities, lithofacies trends, distinctive sedimentological and palaeoecological shifts, condensed intervals, trace fossils and ichnofabric, as well as biostratigraphic and taphonomic trends (Ver Straeten et al., 2011 and references there in). Programmed pyrolysis (commonly known as Rock Eval) is well-suited as a geochemical screening method to characterise the organic matter since it provides data about the type, quantity and the thermal maturity during the initial assessment of source rocks (Clementz et al., 1979; Espitalié et al., 1985b, 1986; Peters, 1986 and Carvajal-Ortiz and Gentzis, 2015). Furthermore, organic petrography is widely regarded as a complementary tool and sometimes superior to bulk analyses. Optical techniques, such as visual kerogen identification and vitrinite reflectance measurements $\left(\% R_{o}\right)$, are extensively used to evaluate the type and thermal maturity evolution of the organic matter in shale petroleum systems (Tissot, 1984 and references therein). In addition, X-Ray diffraction constitutes a valuable tool to determine mineral composition and to evaluate trends related to sedimentological changes throughout a succession. Likewise, calcareous nannofossils help to asses palaeoceanographic and palaeoclimatic changes, due to their extreme sensitivity to environmental perturbations (e.g., Roth and Bowdler, 1981; Erba et al., 2004; Street and Bown, 2000; Melinte and Mutterlose, 2001; Herrle, 2003; Kessels et al., 2003, 2006; Bown, 2005; Watkins et al., 2005; Tremolada et al., 2006; Aguado et al., 2014). The integration of these data constitutes a multiproxy approach to infer the sedimentary environment and the processes during sedimentation.

Therefore, the objectives of the present study are threefold: (1) to document variations in organic matter and mineralogy, (2) to compare these variations with fluctuations recorded in the abundance and composition of nannofossils assemblages, (3) to discuss possible factors that exerted main controls on these variations and their links to environmental changes in the basin during the Late Hauterivian.

\section{Geological setting and chrono-biostratigraphic context}

The Neuquén Basin is a retroarc triangular-shaped basin located east of the Andes in Argentina between $32^{\circ}$ and $40^{\circ} \mathrm{S}$ latitude, primarily within Mendoza and Neuquén provinces (Legarreta and Uliana, 1991). During its evolution was bounded to the east by the cratonic areas of Sierra Pintada System (north-east) and North Patagonian Massif (southeast), and to the west by a stationary magmatic arc (Fig. 1a). Its sedimentary record covers an area of approximately $120.000 \mathrm{~km}^{2}$ (Yrigoyen, 1991) and comprises more than $7 \mathrm{~km}$ thick of marine and continental deposits, accumulated in a variety of basin styles from the late Triassic to the early Cenozoic (Legarreta and Uliana, 1991; Howell et al., 2005). Three main depositional stages can be recognised during the basin evolution. The first stage (Late Triassic-Early Jurassic) was characterised by intraplate extension within Gondwana, where the resulting system of isolated half-graben depocenters controlled the distribution and thickness of volcanic and volcaniclastic materials of the Precuyo Group (Gulisano and Gutiérrez Pleimling, 1995). During the second stage (Early Jurassic-Early Cretaceous), the deposition was controlled by the steady back-arc subsidence related to an active subduction along the western border of Gondwana, which led to periodic connections with the proto-Pacific Ocean through the volcanic arc (Vergani et al., 1995; Franzese et al., 2003). As the result of transgressive-regressive cycles, marine to continental successions were deposited and are represented by the Cuyo, Lotena and Mendoza Groups (Legarreta and Uliana, 1991; Vergani et al., 1995). The total assembly of these deposits hosted multiple petroleum systems that became targets for hydrocarbon exploration in the Neuquén Basin, which is considered as the most important hydrocarbon-producing province in southern South America with $37.774 \mathrm{~m}^{3} /$ day of oil and $91.471 \mathrm{Mm}^{3}$ / day of gas produced (IAPG website, 2019) (Fig. 1b). The third stage, from the Late Cretaceous to the Cenozoic, was characterised by compressional tectonics along the western margin leading to the uplift of the Andean mountain belt and the progressive evolution of a foreland basin (Howell et al., 2005). The marine influence from the Pacific ceased and, as a consequence, the continental deposits of Bajada del Agrio and Neuquén Groups were accumulated as well as the Atlanticrelated marine deposits of the Malargüe Group.

The Agrio Formation (late Early Valanginian-Late Hauterivian) represents the uppermost unit of the Mendoza Group (Groeber, 1953), and is the youngest compared to the other two main source rocks of the basin (Los Molles and Vaca Muerta formations). It is a regionally extensive unit that crops out along the eastern foothills of the Andes, from the vicinity of La Mala Dormida to Catan Lil localities in Mendoza and Neuquén provinces, respectively (Aguirre-Urreta and Rawson, 1997) (Fig. 1a). It reaches a maximum thickness of $\sim 1500-1600 \mathrm{~m}$ in the basin center and is reduced to $\sim 200-300 \mathrm{~m}$ towards the north in Mendoza (Tyson et al., 2005; Spalletti et al., 2011). The Agrio Formation was first described by Weaver (1931) in the Río Agrio section and represents a storm dominated shallow marine environment, with mixed siliciclastic and carbonate sedimentation constituting an excellent example of a rhythmic succession (Spalletti et al., 2001, Lazo et al., 2005, Sagasti, 2002, 2005; Aguirre-Urreta et al., 2019). This unit was divided into three members (Fig. 1b) (Weaver, 1931; Leanza et al., 2001). The Pilmatué Member (lower Agrio) and the Agua de la Mula Member (upper Agrio), are associated with deposition during transgressive periods and are mainly composed of shales interbedded with packstones, wackestones, rudstones and floatstones (Leanza and Hugo, 2001). The central Avilé Member, is characterised as a thin but laterally persistent continental sandstone of mainly fluvial and aeolian origin, marking an abrupt regressive event during the mid-Hauterivian (Gulisano and Gutiérrez Pleimling, 1988; Veiga et al., 2011). Towards the top, the Agrio Formation is unconformably overlain by sandstones, limestones and evaporites of the Huitrín Formation (Bajada del Agrio Group), marking a regressive phase and the beginning of the disconnection between the basin and the Pacific Ocean during the Barremian (Aguirre-Urreta et al., 2019).

The biostrastigraphy of the Neuquén Basin has been studied for decades (Aguirre-Urreta et al., 2005; Concheyro et al., 2009; Ballent et al., 2011, Lescano and Concheyro, 2014, among others) and up to now represents one of the most complete Jurassic-Early Cretaceous marine fossil records in the southern hemisphere. The Agrio Formation is characterised by an abundant and well-preserved paleontological content. The fauna comprises highly diverse infaunal, semi-infaunal and epifaunal organisms and includes gastropods, bivalves, ostracods, nautiloids, ammonoids, serpulids, bryozoans, corals, decapod crustacea and echinoderms (Aguirre-Urreta, 1989, 2003; Aguirre-Urreta and Rawson, 1997; Lazo et al., 2005; Aguirre-Urreta et al., 2011). The nectonic fauna is mainly composed of cephalopods and lesser of fish and marine reptiles (Cichowolski and Lazo, 2000; Spalletti et al., 2011). This fauna has predominantly Tethyan affinities, however Andean affinity and even endemic taxa are also present (Aguirre-Urreta et al., 2008), indicating shallow and warm-temperate waters (Lazo et al., 2005).

\section{Study interval}

In this work, $\mathrm{a} \sim 220 \mathrm{~m}$ thick succession of the Agua de la Mula Member was described at the El Portón section situated $22 \mathrm{~km}$ southeast of Buta Ranquil and about ca. $7 \mathrm{~km}$ from the El Portón oil field (Fig. 2). This area is part of a productive triangle zone located in front of the Chosmalal fold and thrust belt that was formed during the Andean orogeny (Kozlowski et al., 1996; Rojas Vera et al., 2015). This 


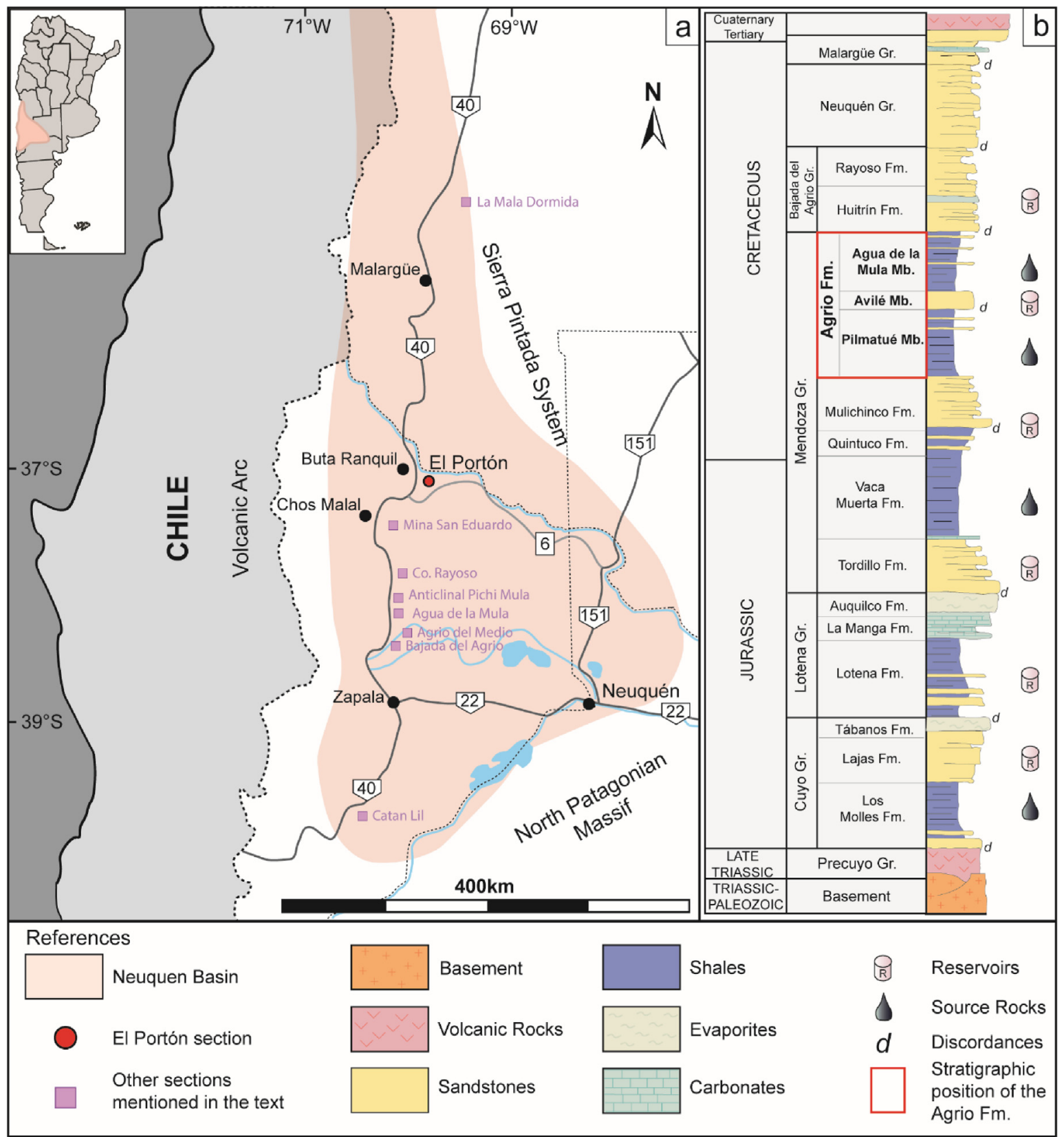

Fig. 1. a) The Neuquén Basin in west-central Argentina and localities cited in the text. b) Generalized stratigraphic column of the Neuquén Basin.

section, corresponds to the central portion of the Neuquén Basin where outer ramp deposits crop out with a high quality of exposure, making this locality a key area for multidisciplinary studies.

The Agua de la Mula Member corresponds to the upper-most member of the Agrio Formation deposited along a south to north trend. Based on the well-established ammonite, nannofossil and palynomorph biostratigraphic framework, the Agua de la Mula deposits are dated into the Late Hauterivian (Aguirre-Urreta et al., 1999, 2005, 2015; Concheyro et al., 2009; Lescano and Concheyro, 2009). Furthermore, three high precision radioisotopic ages calibrated with CA-ID-TIMS $\mathrm{U}-\mathrm{Pb}$ zircon ages have been presented for the Agua de la Mula Member. A tuff level of the sequence studied in this section provided an age of $126.97 \pm 0.15 \mathrm{Ma}$, and two others from Caepe Malal and Agrio del Medio localities, $129.09 \pm 0.04 \mathrm{Ma}$ and $127.42 \pm 0.03 \mathrm{Ma}$, respectively (Aguirre-Urreta et al., 2015, 2019).

\section{Materials and methods}

\subsection{Sedimentology}

The Agua de la Mula Member was logged at a scale 1:500 using a Jacob's staff. The section was described on a bed-to-bed basis with particular emphasis on lithology, bedding geometries, sedimentary structures, body fossils, trace fossils, and rock colour. Sedimentary facies (SF) were defined in order to recognise depositional processes and the genetically related SFs were grouped in facies associations (FA) to represent parts of a depositional system. Thirty-one samples were collected along the section, with an average spacing of $7.5 \mathrm{~m}$. The sedimentary rock classification scheme follows the criteria of Macquaker and Adams (2003). The uppermost $20 \mathrm{~m}$ of the section were not measured, and no samples were taken from this interval. 


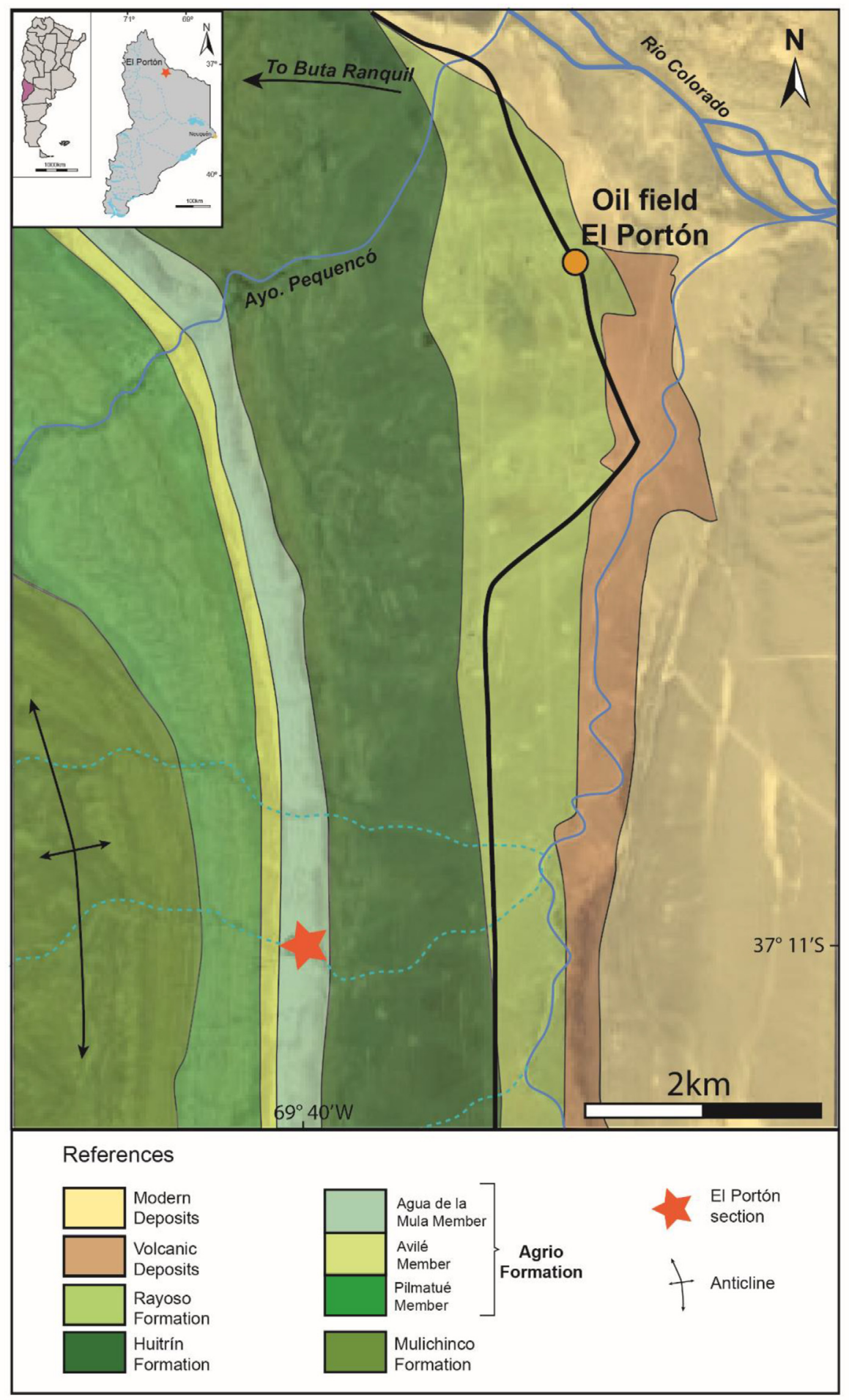

Fig. 2. Geological map showing the main units and the location of the El Portón section in the Neuquén Basin (west-central Argentina).

\subsection{Organic geochemistry}

Thirty-one samples were analysed using a Rock Eval 6 pyrolysis unit at Y-TEC laboratories (La Plata, Argentina), in order to obtain information of the Total Organic Carbon (TOC), type of kerogen and thermal maturity of the preserved organic matter. The samples were first pulverised to $\sim 100 \mu \mathrm{m}$ size and then $\sim 70 \mathrm{mg}$ weighted into stainless steel crucibles. A detailed revision and description of the geochemical data routinely provided by this instrument can be found in
Clementz et al. (1979), Peters (1986), Jarvie (1991), Peters and Casa (1994), Behar et al. (2001) and Hart and Steen (2015). Briefly, during a standard cycle every powdered sample is placed in an oven filled with an inert gas (helium or nitrogen), it is first pyrolysed and subsequently completely oxidised. During the first stage of pyrolysis, a Flame Ionization Detector (FID) measures the amount of free hydrocarbons already present in the sample and thermally extractable at $300^{\circ}\left(\mathrm{S}_{1}\right.$, $\mathrm{mgHc} / \mathrm{g}$ rock), and during the second stage it measures the amount of hydrocarbons generated through thermal cracking of non-volatile 
organic matter between 300 and $650^{\circ}\left(\mathrm{S}_{2}, \mathrm{mgHc} / \mathrm{g}\right.$ rock). The $\mathrm{CO}_{2}$ and the $\mathrm{CO}$ yield during the pyrolysis stage $\left(\mathrm{S}_{3}, \mathrm{mgHc} / \mathrm{g}\right.$ rock) are determined using an infrared detector. After pyrolysis is complete, the sample is combusted to obtain the residual carbon $\left(\mathrm{S}_{4}, \mathrm{mgCO}_{2} / \mathrm{g}\right.$ rock) and the oxidised mineral-carbon $\left(\mathrm{S}_{5}, \mathrm{mgCO}_{2} / \mathrm{g}\right.$ rock). The Rock Eval also determines the Total Organic Carbon (TOC) content by integrating the FID, $\mathrm{CO}$ and $\mathrm{CO}_{2}$ signals during pyrolysis and oxidation stages, and records the oven temperature at which the maximum release of hydrocarbons is reached during pyrolysis $\left(\mathrm{T}_{\max }\right)$. In addition, two other derived parameters are obtained, the Hydrogen Index (HI) and the Oxygen Index (OI). The $\mathrm{HI}$ is defined as the ratio $\mathrm{S}_{2} / \mathrm{TOCx} 100$ and related to the origin and maturity of the kerogen, while the OI is determined as $S_{3} / T O C x 100$ which corresponds to the carbon dioxide quantity released during the kerogen combustion.

\subsection{Organic petrography}

In this work, analyses were performed on three polished whole rock mounts at Y-TEC laboratories (La Plata, Argentina), which were selected according to their higher organic content determined by pyrolysis. For the determination of vitrinite reflectance, samples were hand-crushed with a mortar and pestle, separated into quarters to ensure representativeness and then sieved with a 20 mesh $(850 \mu \mathrm{m}$ or $0.85 \mathrm{~mm}$ size particles). The retained fraction was placed in speciallydesigned molds, embedded with a mixture of epoxy resin (EpoFix Resin de Struers) and epoxy hardener (EpoFix Hardener de Struers), and left to harden for approximately $24 \mathrm{~h}$. The epoxy plugs were polished to specular surface for microscopic examination. Macerals were identified using a Carl Zeiss Axio Imager A2m microscope, and the maturity from vitrinite reflectance measurements $\left(\% \mathrm{R}_{\mathrm{o}}\right)$ was estimated using a CRAIC PV 508 equipment and the Coal Pro software. The aperture diameter selected was $5 \mu \mathrm{m}$, to provide an effective field of view. Calibration was made using three international reference standards (0,421-Spinel; $0,896-$ YAG and 1,710-GGG).

For visual kerogen analyses, the organic matter concentration process followed standard laboratory procedures (Volkheimer and Melendi, 1976). Treatment of hydrochloric and hydrofluoric acid removed carbonates and silicates. Residues were sieved with a $10 \mu \mathrm{m}$ mesh and mounted on glass slides using glycerin jelly. The concentrated kerogens and the accurate distinction of its components were performed under transmitted light and blue light fluorescence with a Zeiss A2m Imager binocular microscope. The colour and intensity of fluorescence were analysed herein in order to assess the maturity of the organic matter (Riecker, 1962; Tyson, 1995).

\section{4. $X R D$ and calcimetry analyses}

A total of nineteen samples were selected for XRD analyses of whole-rock and clay fraction $(<2 \mu \mathrm{m})$. XRD analyses were run on a PANanlytical model X'Pert PRO diffractometer at the Centro de Investigaciones Geológicas (La Plata, Argentina), using $\mathrm{Cu}$ radiation $(\mathrm{K} \alpha=1.5405 \mathrm{~A})$ and $\mathrm{Ni}$ filter and generation settings of $40 \mathrm{kV}$ and $40 \mathrm{~mA}$.

Samples were subjected to soft grinding with a rubber mortar and repeatedly washed in distilled water until deflocculation of clays occurred. XRD patterns from randomly oriented mounts (whole rock) of the powdered samples were run from $3^{\circ}$ to $37^{\circ} 2 \theta$ for $3 \mathrm{~h}$ and the semiquantification was obtained from the intensity of the main peak for each mineral. The estimation of the mineralogical components is classified according to the following abundances: traces (tr: $<1 \%$ ), very scarce (vs: $1-5 \%$ ), scarce (s: 6-15\%), moderate (m: 16-30\%), abundant (a: $31-50 \%$ ), very abundant (va: $51-70 \%$ ) and extremely abundant (ea: 71-100\%).

Oriented clay fraction $(<2 \mu \mathrm{m})$ was separated by gravity settling in suspension and oriented mounts were prepared on a glass slide. The clay mineralogy of the oriented samples was determined in the following conditions: air-dried, ethylene glycol-solvated and heated to $550{ }^{\circ} \mathrm{C}$ for $2 \mathrm{~h}$ (Brindley, 1961; Brown, 1980). Routine air-dried mounts were run between 2 and $32^{\circ} 2 \theta$ at a scan speed of $2{ }^{\circ} 2 \theta / \mathrm{min}$. Ethylene glycol-solvated and heated samples were run from 2 to $27^{\circ} 2 \theta$ and 3-15 ${ }^{\circ} 2 \theta$ respectively, at a scan speed of $2{ }^{\circ} 2 \theta / \mathrm{min}$. Semi-quantitative estimations of the relative percentages of clay minerals were based on the peak area method (Biscaye, 1965) on glycolated samples (001 for illite, smectite, kaolinite and illite/smectite mixed layer; 002 for chlorite) by applying empirical factors (Moore and Reynolds, 1989). Semi-quantification was sufficient to define clay mineral assemblages, because the presence/absence or dominant/subordinate relationships clearly allowed distinguishing different groups. The diffractograms of the bulk and clay samples were evaluated using the software X'Pert High Score.

The measurements of the carbonate contents were performed with a Bernard-type calcimeter at the Instituto de Investigación en Paleobiología y Geología (Río Negro, Argentina). This is one of the most common methods, that quantifies the relative concentrations of carbonates by treating the sample with $\mathrm{HCl}$ acid in an enclosed reaction cylinder. The carbon dioxide formed by the reaction, pushes the water of the graduated cylinder and the measurement of the quantity of carbonate originally present in the sample is directly read on the scale.

\subsection{Calcareous nannofossils}

Thirty samples were analysed for calcareous nannofossils. Sample spacing was uneven and fluctuates between $2 \mathrm{~m}$ and $18 \mathrm{~m}$ (with an average of $7.5 \mathrm{~m}$ ).

Samples were prepared following the smear slide technique (Edwards, 1963). The slides were fixed with UV curing Norland Optical Adhesive. Special care was taken to prepare the samples as uniformly as possible, in order to have comparable slides. Identification and photographs of calcareous nannofossils were carried out with a Leica DMLP petrographic microscope, using a 1000x magnification and accessories as lambda gypsum plate. The slides are housed in the Area Paleontología, Facultad de Ciencias Exactas y Naturales, Universidad de Buenos Aires, under catalog numbers BAFC-NP 4040-4098.

Following the guidelines proposed by Bown and Young (1997), calcareous nannofossils slides were examined in order to identify all taxa that could have biostratigraphic importance. Analyses of the assemblage composition consisted in quantifying the specimens along a 400 fields of view (two longitudinal traverse $=400$ fields of view). Rare taxa that might be missed has been analysed with additional transects examinations. Coccoliths were included in the counts only if more than a half of the specimen examples were preserved. The total abundance of nannofossils per sample was calculated as the number of counted specimens divided by 400 fields of vision required to count. In order to identify stratigraphic changes in the assemblage composition, the percentage of individual species was calculated for each sample comparing it against the total number of nannofossils.

To facilitate the quantitative analyses, some taxa were identified at species level and grouped at a generic level such as Cyclagelosphaera spp. (C. margerellii and rare C. brezae, C. lacuna, C. deflandrei) and Micrantholithus spp. (M. hoschulzii and M. obtusus). Erba (1994) subdivides the genus Nannoconus according to the diameter of the central cavity. In this study, the narrow-canal group is represented by $N$. steinmannii and $N$. elongatus, while the wide channel forms consist mainly of $N$. bucheri, $N$. circularis, $N$. globulus and N. kamptneri. Watznaueria spp. primarily includes $W$. barnesiae, $W$. biporta, $W$. fossacincta, $W$. manivitae and W. ovata. It is important to clarify that "other species" were grouped together with "other Nannoconus" (to include $N$. truitti truitti, N. truitti frequens, N. quadriangulus quadriangulus, N. quadriangulus apertus) and other taxa of the genus Cretarhabdus, Crucibiscutum, Eprolithus, Retecapsa, Rhagodiscus, Staurolithites, Tubodiscus, Zeugrhabdotus and species displaying low abundances such as Assipetra terebrodentarius, Axopodorhabdus sp., Bukrylithus ambiguous, Calculites sp., Clepsilithus maculosus, Diazomatholithus lehmanii, Eiffellithus striatus, 
Table 1

Nannofossils abundance percentages of Watznaueria spp., Micrantholithus spp., narrow and wide canal Nannoconus, Cyclagelosphaera spp. and “other species”.

\begin{tabular}{|c|c|c|c|c|c|c|c|c|}
\hline Samples & Height (mts.) & Specimen/Visual range & Watznaueria spp. & Micrantholithus spp. & Nannoconus narrow & Nannoconus wide & Cyclagelosphaera spp. & Others \\
\hline 1724 & 216.0 & 2.33 & 1.39 & 30.41 & 59.64 & 0.32 & 4.39 & 3.85 \\
\hline 1710 & 213.0 & 0.16 & 69.70 & 1.52 & 1.52 & 0.00 & 0.00 & 27.27 \\
\hline 1679 & 205.5 & 0.69 & 25.45 & 30.18 & 14.55 & 12.00 & 5.09 & 12.73 \\
\hline 1630 & 192.5 & 6.86 & 94.17 & 4.74 & 0.22 & 0.00 & 0.00 & 0.87 \\
\hline 1600 & 186.0 & 6.13 & 67.62 & 13.21 & 4.40 & 2.81 & 0.04 & 11.91 \\
\hline 1544 & 172.0 & 3.15 & 91.44 & 1.27 & 0.00 & 0.00 & 1.58 & 5.71 \\
\hline 1475 & 154.0 & 0.00 & 0.00 & 0.00 & 0.00 & 0.00 & 0.00 & 0.00 \\
\hline 1443 & 146.0 & 10.04 & 69.89 & 9.13 & 2.09 & 2.94 & 0.25 & 15.70 \\
\hline 1414 & 138.5 & 3.34 & 57.90 & 8.61 & 6.67 & 11.61 & 0.22 & 14.98 \\
\hline 1391 & 132.5 & 7.91 & 74.98 & 11.02 & 1.23 & 3.32 & 0.00 & 9.44 \\
\hline 1352 & 123.0 & 2.74 & 78.12 & 9.12 & 4.65 & 0.64 & 0.27 & 7.20 \\
\hline 1317 & 114.0 & 0.64 & 84.38 & 0.00 & 0.00 & 0.00 & 8.59 & 7.03 \\
\hline 1294 & 108.5 & 7.71 & 74.22 & 11.61 & 3.44 & 0.84 & 1.95 & 7.94 \\
\hline 1259 & 99.8 & 3.44 & 71.20 & 16.51 & 2.55 & 1.02 & 5.09 & 3.64 \\
\hline 1196 & 84.0 & 6.32 & 51.25 & 15.75 & 4.59 & 14.52 & 1.11 & 12.78 \\
\hline 1151 & 72.5 & 3.59 & 52.92 & 22.14 & 7.94 & 1.81 & 1.74 & 13.44 \\
\hline 1143 & 70.5 & 2.81 & 59.29 & 13.96 & 5.24 & 0.62 & 1.78 & 19.11 \\
\hline 1136 & 68.5 & 4.82 & 79.89 & 4.72 & 0.41 & 0.10 & 11.82 & 3.06 \\
\hline 1114 & 63.0 & 1.36 & 41.25 & 0.00 & 0.00 & 0.00 & 53.96 & 4.79 \\
\hline 1082 & 55.0 & 3.10 & 69.22 & 1.93 & 1.77 & 1.85 & 20.55 & 4.67 \\
\hline 1058 & 49.5 & 4.14 & 57.52 & 14.50 & 4.17 & 6.95 & 13.47 & 3.38 \\
\hline 1043 & 45.5 & 3.92 & 68.94 & 5.93 & 13.52 & 1.28 & 0.19 & 10.14 \\
\hline 995 & 33.0 & 9.64 & 86.98 & 7.89 & 1.87 & 0.36 & 0.54 & 2.36 \\
\hline 985 & 30.0 & 7.26 & 70.08 & 19.73 & 1.31 & 3.03 & 0.79 & 5.06 \\
\hline 958 & 26.0 & 8.80 & 91.31 & 2.39 & 0.34 & 0.62 & 0.11 & 5.22 \\
\hline 949 & 21.0 & 4.66 & 89.22 & 1.29 & 2.90 & 0.16 & 4.56 & 1.88 \\
\hline 920 & 14.0 & 0.74 & 80.47 & 11.78 & 0.00 & 1.68 & 0.34 & 5.72 \\
\hline 913 & 12.0 & 0.37 & 61.49 & 32.43 & 4.73 & 0.00 & 0.00 & 1.35 \\
\hline 887 & 5.0 & 0.57 & 30.26 & 64.47 & 1.75 & 0.00 & 0.00 & 3.51 \\
\hline 879 & 0.0 & 0.00 & 0.00 & 0.00 & 0.00 & 0.00 & 0.00 & 0.00 \\
\hline
\end{tabular}

Etmorhabdus hauterivianus, Helenea chistia, Manivitella pemmatoidea, Markalius inversus, Percivalia fenestrata, Cervisiella sp. (Appendix A).

Only the taxa present in $5 \%$ or greater were selected for statistical analyses, such as: Nannoconus narrow channel, Nannoconus wide channel, Cyclagelosphaera spp., Micrantholithus spp., Watznaueria spp and "other species" (Table 1).

\section{Results}

\subsection{Lithology of the El Portón section}

Six sedimentary facies (SF) were recognised within the Agua de la Mula Member and were grouped into two facies associations (FA) (Fig. 3). The FAs described below were organized in a stratigraphic order from base to top.

\subsubsection{Facies association 1 (FA1): distal outer ramp}

Description and interpretation: these deposits are characterised by mudstone bodies with an external tabular geometry, reaching up to $3.6 \mathrm{~m}$ thick and $>0.5 \mathrm{~km}$ of lateral extension. Internally, it is defined by tabular strata delimitated by planar bases and tops, and displaying a thinning upward arrangement. Individual tabular beds are up to $0.7 \mathrm{~m}$ that, exceptionally, form groups of considerable thickness, and consists of rhythmic intercalations of micrite-dominated mudstones distinguished into massive mudstones $(\mathrm{Mm})$ and massive wackestones (Mw). In a lesser proportion, massive calcareous shales (Mcs) and massive marlstones (Mms) are interbedded, with a variable thickness between 0.02 and $3.6 \mathrm{~m}$. Occasionally, $0.05-0.10 \mathrm{~m}$ levels of clay-altered massive tuff (Mt) are observed interbedding throughout the section. Bioclastic material includes foraminifers, ammonites, small long spired gastropods, non-articulated but complete valves of inoceramids and phytodetritus. This facies association is interpreted to represent settling from suspension during fair-weather conditions below the storm-wave base and with high carbonate productivity, suggesting deposition in the most distal and poorly oxygenated part of the outer ramp setting (Burchette and Wright, 1992). The presence of tuff deposits denotes the influence of an active volcanic arc.

\subsubsection{Facies association 2 (FA2): proximal outer ramp}

Description and interpretation: deposits of FA2 consist of tabular packages up to $13.6 \mathrm{~m}$ thick and laterally continuous for several kilometers. The packages are composed of tabular strata of mudstones, delimitated by planar bases and tops, and displaying a thinning and/or thickening upward arrangement. The association initiates with micritedominated mudstones that is replaced rapidly upwards by the rhythmic intercalation of massive calcareous shales (Mcs) and massive marlstones (Mms) (0.02-13.6 cm thick). Massive tuff (Mt) are observed interbedded, as well as micrited-dominated facies which occur less frequently in comparison with FA1. The association culminates with massive dolomites (Md). Fragments of bivalves and ammonites are concentrated at some levels. The FA2 was deposited from suspension fall-out in a more proximal setting, but still below the storm-wave base (Burchette and Wright, 1992).

\subsection{Programmed pyrolysis}

The geochemical characteristics of the Agua de la Mula Member are summarised in Table 2. In order to achieve analytical precision for an accurate interpretation of the data, we selected those results which are representative considering certain geochemical criteria. In this sense, the "Reesa" rules (Peters and Nelson, 1992) were applied which express the cut-off values for each parameter determined by pyrolysis. Only the samples in-between the following values were considered: TOC $\geq 0,3$ wt $\%, S_{2} \geq 0.2 \mathrm{mg} \mathrm{HC} / \mathrm{g}$ rock, $\mathrm{HI} \geq 50 \mathrm{mg} \mathrm{HC} / \mathrm{g}$ TOC and $\mathrm{T}_{\max }$ $\geq 395^{\circ}$.

The studied samples are characterised by TOC values ranging between 0.35 and $4.43 \mathrm{wt} \%$ (mean value $=1.29 \mathrm{wt} \%, n=21$ ). Three noticeable peaks are observed along the section. The first one is recorded at the base in sample EPJ890, which represents the highest value throughout the studied interval (4.43 wt\%). The second peak is 


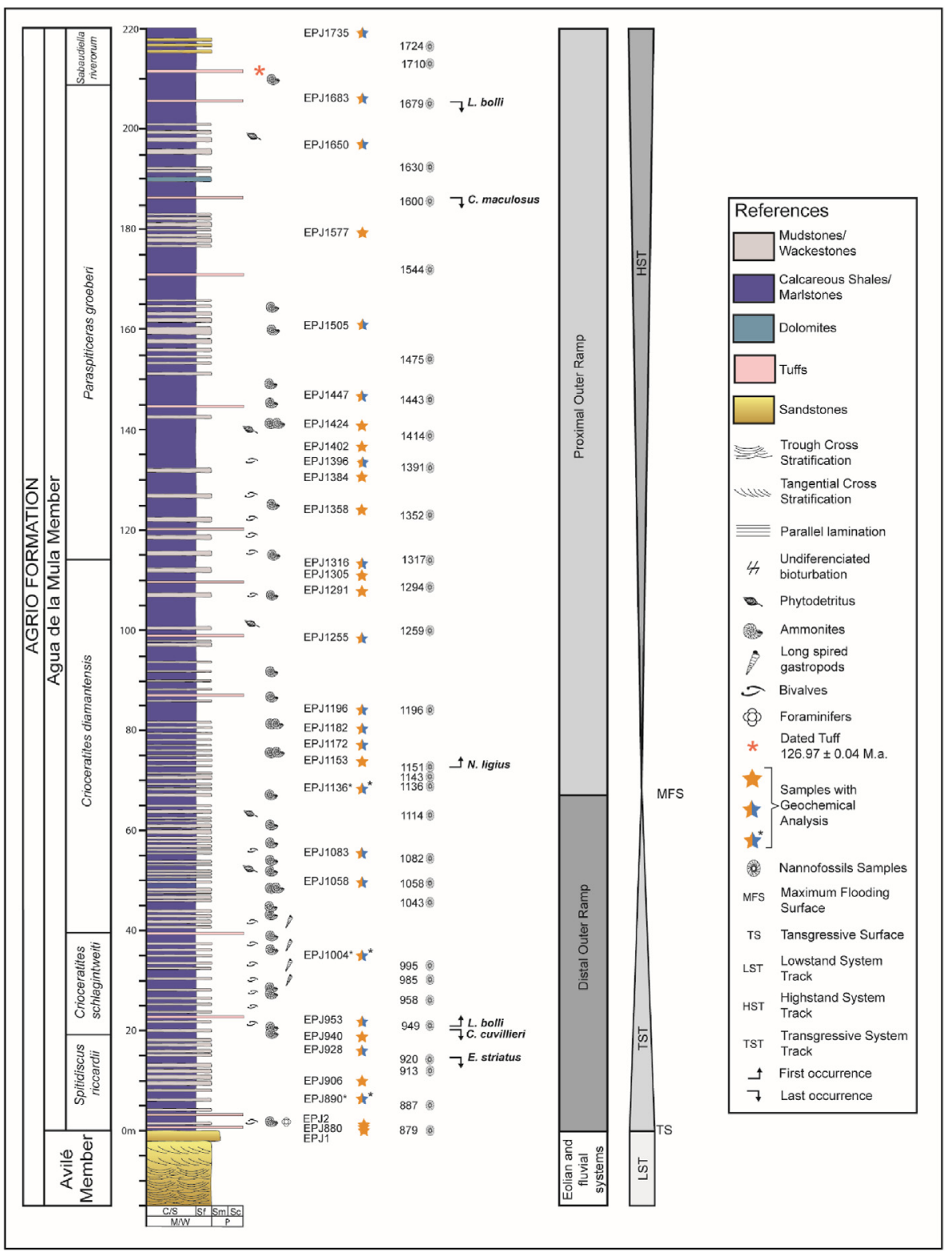

Fig. 3. Lithostratigraphy of the Agua de la Mula Member of the Agrio Formation at the El Portón locality. The biozonation is based on Aguirre-Urreta et al. (2005, 2015, 2019). Coloured stars indicate geochemical analyses: orange: programmed pryrolysis; orange and light blue: programmed pryrolysis, X-ray diffraction and calcimetry; orange and light blue with asterisk: programmed pryrolysis, X-ray diffraction, calcimetry and organic petrography. (For interpretation of the references to colour in this figure legend, the reader is referred to the Web version of this article.)

registered in sample EPJ1136 (3.60 wt\%) and the third is observed in sample EPJ1396 (1.95 wt\%). The data shows high TOC values with progressive decreasing trend towards shallower settings.

Other pyrolysis parameters considered here for further interpretations are $S_{2}, H I$, OI and $T_{\max }$. The $S_{2}$ values vary between 0.23 and $24.87 \mathrm{mgHC} / \mathrm{g}$ rock. The HI and OI range from 50 to $561 \mathrm{mgHC} / \mathrm{g}$ TOC and from 12 to $209 \mathrm{mgCO}_{2} / \mathrm{g}$ TOC, respectively. $\mathrm{T}_{\max }$ values are fairly consistent between 430 and $444{ }^{\circ} \mathrm{C}$. These results are presented in diagrams that provide information about the kerogen type and therefore, palaeoenvironmental interpretations can be made. These plots are HI against OI (Pseudo Van Krevelen), $S_{2}$ against present-day TOC, and $\mathrm{HI}$ against $\mathrm{T}_{\max }$ (Fig. 4a, b and c, respectively).

\subsection{Organic petrography}

Based on the petrographic observations, the samples EPJ890, EPJ1004 and EPJ1136 are accounted for a high organic matter content, mainly in small-sized fraction. The visual kerogen studies under transmitted light (Fig. 5a, b and c) showed an assemblage characterised by marine-derived amorphous organic matter -AOM-considered to be algal in origin, with subordinate opaque and translucent phytoclasts debris and miospores in a 90/10 ratio. Palynomorphs are very scarce. The pollen grains are represented by miospores most likely assignable to the Cheirolepidiaceae (Classopollis sp.) (Fig. 5b) and the Araucariaceae (Araucariacites sp.) (Fig. 5c). Indeterminate dinoflagellate cysts also occur.

Examination under incident light shows that the three samples have unvaried characteristics regarding the kerogen composition. However, it is remarkable that sample EPJ890 shows the highest proportion of oxydised organic matter dominated by terrestrial inertinite, and sample EPJ1136 shows the largest vitrinite particles (Fig. 5d, e and f). The AOM (up to 90\%) is represented mainly by the spongy and finely divided algae type, with a moderate orange to golden yellow fluorescence (fluorescence scale after Tyson, 1995) (Fig. 5g, h and i). 
Table 2

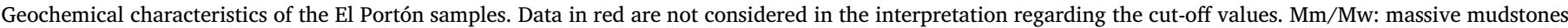
and massive wackestones facies. Mcs/Mms: massive calcareous shales and massive marlstones.

\begin{tabular}{|c|c|c|c|c|c|c|c|c|c|}
\hline Samples & Height (mts.) & Lithology & $\mathrm{CaCO}_{3}(\%)$ & TOC (in weight \%) & $\mathrm{S}_{2}$ (mgHc/g rock) & HI (mgHc/gTOC) & $\mathrm{OI}\left(\mathrm{mgCO}_{2} / \mathrm{gCOT}\right)$ & $\operatorname{Tmax}\left({ }^{\circ} \mathrm{C}\right)$ & Vitrinite $\left(\% \mathrm{R}_{\mathrm{O}}\right)$ \\
\hline EPJ1735 & 219.0 & $\mathrm{Mcs} / \mathrm{Mms}$ & 39.4 & 0.24 & 0.10 & 42 & 250 & 445 & - \\
\hline EPJ1683 & 206.0 & $\mathrm{Mcs} / \mathrm{Mms}$ & 12.8 & 0.50 & 0.10 & 20 & 239 & 434 & - \\
\hline EPJ 1650 & 197.0 & Mcs/Mms & 42.9 & 0.45 & 0.36 & 80 & 136 & 444 & - \\
\hline EPJ1577 & 179.5 & Mcs/Mms & 61.3 & 0.28 & 0.20 & 70 & 197 & 444 & - \\
\hline EPJ1505 & 161.0 & $\mathrm{Mcs} / \mathrm{Mms}$ & 52.5 & 0.37 & 0.46 & 123 & 209 & 437 & - \\
\hline EPJ1447 & 146.0 & $\mathrm{Mcs} / \mathrm{Mms}$ & 51.0 & 0.45 & 0.23 & 51 & 160 & 443 & - \\
\hline EPJ 1424 & 141.0 & Mcs/Mms & - & 0.87 & 1.68 & 193 & 82 & 440 & - \\
\hline EPJ 1402 & 136.5 & Mcs/Mms & - & 1.20 & 3.55 & 296 & 52 & 435 & - \\
\hline EPJ1396 & 132.5 & $\mathrm{Mcs} / \mathrm{Mms}$ & 42.1 & 1.95 & 6.39 & 341 & 35 & 432 & - \\
\hline EPJ 1384 & 131.0 & Mcs/Mms & - & 0.37 & 0.18 & 49 & 208 & 445 & - \\
\hline EPJ 1358 & 123.0 & $\mathrm{Mcs} / \mathrm{Mms}$ & - & 0.40 & 0.14 & 35 & 178 & 448 & - \\
\hline EPJ1316 & 114.0 & $\mathrm{Mcs} / \mathrm{Mms}$ & 15.8 & 0.34 & 0.11 & 32 & 138 & 512 & - \\
\hline EPJ 1305 & 111.0 & Mcs/Mms & - & 0.29 & 0.05 & 17 & 190 & 449 & - \\
\hline EPJ 1291 & 108.5 & $\mathrm{Mcs} / \mathrm{Mms}$ & - & 0.51 & 0.17 & 33 & 122 & 445 & - \\
\hline EPJ1255 & 99.8 & $\mathrm{Mcs} / \mathrm{Mms}$ & 35.7 & 0.49 & 0.24 & 49 & 141 & 444 & - \\
\hline EPJ1196 & 84.0 & $\mathrm{Mcs} / \mathrm{Mms}$ & 48.7 & 1.09 & 1.66 & 152 & 82 & 439 & - \\
\hline EPJ1182 & 80.0 & $\mathrm{Mm} / \mathrm{Mw}$ & 69.3 & 1.60 & 5.80 & 362 & 36 & 430 & - \\
\hline EPJ1172 & 77.0 & $\mathrm{Mm} / \mathrm{Mw}$ & 59.6 & 1.88 & 9.59 & 492 & 17 & 432 & - \\
\hline EPJ 1153 & 72.5 & $\mathrm{Mm} / \mathrm{Mw}$ & - & 1.86 & 9.09 & 489 & 25 & 434 & - \\
\hline EPJ1136* & 68.5 & $\mathrm{Mm} / \mathrm{Mw}$ & 62.4 & 3.60 & 16.94 & 471 & 28 & 430 & 0.65 \\
\hline EPJ 1083 & 55.0 & Mcs/Mms & - & 2.19 & 7.75 & 354 & 48 & 437 & - \\
\hline EPJ1058 & 49.5 & $\mathrm{Mm} / \mathrm{Mw}$ & 70.7 & 1.11 & 3.74 & 337 & 41 & 433 & - \\
\hline EPJ1004* & 35.0 & $\mathrm{Mm} / \mathrm{Mw}$ & 80.9 & 1.24 & 6.78 & 520 & 28 & 433 & 0.61 \\
\hline EPJ 953 & 22.0 & $\mathrm{Mm} / \mathrm{Mw}$ & - & 0.41 & 0.54 & 132 & 134 & 442 & - \\
\hline EPJ 940 & 19.0 & Mcs/Mms & - & 0.36 & 0.37 & 103 & 192 & 440 & - \\
\hline EPJ928 & 16.0 & $\mathrm{Mm} / \mathrm{Mw}$ & 64.2 & 0.92 & 1.72 & 187 & 82 & 438 & - \\
\hline EPJ 906 & 10.0 & $\mathrm{Mcs} / \mathrm{Mms}$ & - & 0.35 & 0.26 & 74 & 203 & 440 & - \\
\hline EPJ890* & 6.0 & $\mathrm{Mm} / \mathrm{Mw}$ & 81.2 & 4.43 & 24.87 & 561 & 12 & 433 & 0.62 \\
\hline$E P J-2$ & 1.0 & Mcs/Mms & - & 0.67 & 0.11 & 16 & 51 & 460 & - \\
\hline EPJ880 & 0.5 & $\mathrm{Mm} / \mathrm{Mw}$ & - & 0.53 & 0.07 & 13 & 28 & 492 & - \\
\hline$E P J-1$ & 0.0 & $\mathrm{Mcs} / \mathrm{Mms}$ & - & 0.49 & 0.10 & 20 & 39 & 506 & - \\
\hline
\end{tabular}

The visual kerogen analyses (Fig. 5) and the vitrinite measurements $\left(\% \mathrm{R}_{\mathrm{o}} 0.61\right.$ to 0.65$)$, together with the Rock Eval pyrolysis data (Table 2), suggest that the samples have a good source potential capable of generating mainly oil, but have not been subjected to high enough temperatures which is consistent with the thermal maturities in the early oil window (Fig. 4c).

\subsection{Mineral composition}

According to the whole-rock compositional data, calcite, quartz, plagioclase and/or K-feldspar and clays are the main detrital components. The calcite is abundant to extremely abundant, quartz varies from scarce to very abundant, the plagioclase is scarce, the K-feldspar is very scarce, and clays range from extremely scarce to scarce. Other identified components are dolomite, siderite, and pyrite which appear in trace proportion. The relative abundance of different minerals is summarised in Table 3 and Fig. 6b. Clay-fraction XRD analyses indicate that illite and mixed-layers illite-smectite are the dominant clay minerals ( $\sim 45 \%$ on average each). Kaolinite is recognised throughout the succession $(\sim 5.5 \%$ on average), while chlorite is registered in the middle section of the unit ( $\sim 10 \%$ on average) (Fig. $6 \mathrm{c}$ ).

Based on the presence, type and relative amount of the abovementioned clay minerals, two clay-mineral assemblages have been identified in the Agua de la Mula Member. The first assemblage is illite and mixed layer illite-smectite associated with kaolinite (I1), and the second assemblage is illite and mixed layer illite-smectite associated with chlorite and kaolinite (I2). The I1 is the most widespread clay mineral assemblage and is characteristically of FA1 mudstones and wackestones. The I2 is restricted to the middle section of the unit within FA2 calcareous shales and marlstones deposits.

The calcimetry curve indicates a pronounced $\mathrm{CaCO}_{3}$ variation, ranging from 81.24 to $12.85 \%$ (mean value $=52.44 \%, n=18$ ). A welldefined trend is observed along the section (Fig. 6d), where three horizons can be distinguished. The first horizon is identified at the base of the section with the highest values remaining quite steady from 81.24 to $70.73 \%$, following the second horizon with gradually decreasing values from 62.36 to $15.78 \%$. Upwards, the third horizon is recognised with values from 42.11 to $52.54 \%$ showing a pronounced decrease towards the top of the interval where the lowest value is registered (12.86\%).

\subsection{Calcareous nannofossils assemblages}

Calcareous nannofossils assemblages from thirty different levels of the Agua de la Mula Member were studied in detail. The nannofloristic assemblage observed in the samples is represented by 60 species and 27 genera and are listed in Appendix A.

In the El Portón section, markers such as Eiffellithus striatus, Cruciellipsis cuvillieri, Lithraphidites bollii, Clepsilithus maculosus, Nannoconus ligius have been identified, while some others have not been recognised (e.g. Speetonia colligata). The FO (First Occurrence) and LO (Last Occurrence) of marker species define bioevents, and six of them have been identified throughout the Agua de la Mula Member and correlated with ammonite zones. On the basis of the recognised bioevents the CC4A, CC4B and CC5 Mediterranean zones/subzones have been identified within the studied range (Sissingh, 1977; Applegate and Bergen, 1988). Moreover, a bioevent considered as Boreal (LO of Clepsilithus maculosus) has also been recognised herein (Rutledge and Bown, 1996).

In the lowermost part of the Agua de la Mula Member the LO of Eiffellithus striatus is recorded with Spitidiscus riccardii ammonite zone (sample BAFC-NP 4042). The FO of L. bollii and LO of Cruciellipsis cuvillieri (BAFC-NP 4043) have also been determined in the lower part of the section together with the Crioceratites schlagintweiti ammonoid zone. The FO of L. bollii was used by Applegate and Bergen (1988) to separate the CC4A and CC4B subzones. The FO of Nannoconus ligius is considered 


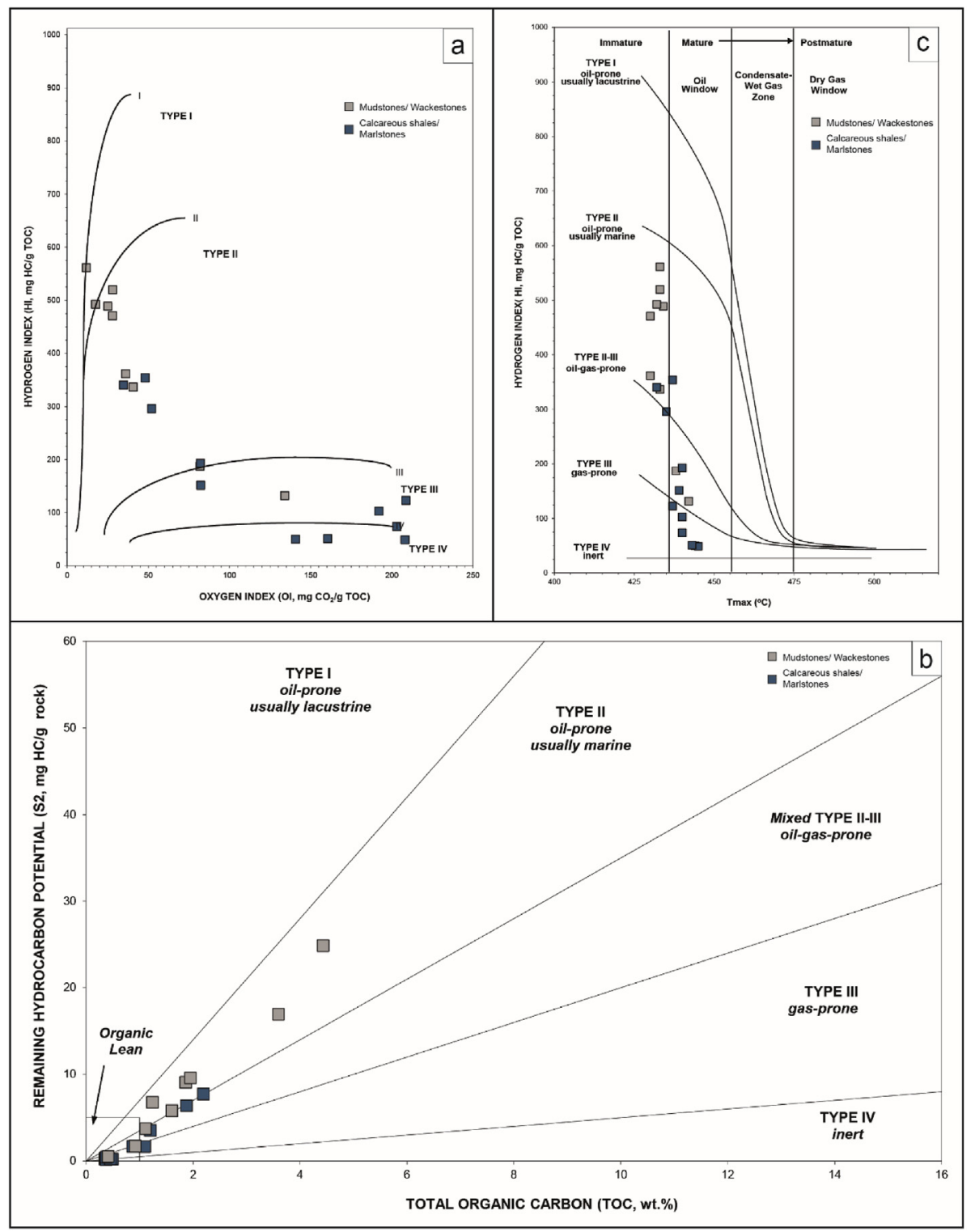

Fig. 4. Programmed pyrolysis data of the Agua de la Mula Member at the El Portón locality. (a) Pseudo Van Krevelen diagram, (b) kerogen quality diagram and (c) kerogen type and maturity diagram. Massive mudstones $(\mathrm{Mm})$ and massive wackestones $(\mathrm{Mw}$ ) facies have higher organic contents and $\mathrm{HI}$ than the massive calcareous shales (Mcs) and massive marlstones facies (Mms) facies. Samples are immature to early mature in this interval.

as a secondary bioevent within the CC4B nannofossil subzone (Applegate and Bergen, 1988). This FO was recorded here in the sample BAFC-NP 4060 and correlated with the middle part of Crioceratites diamantensis ammonite zone. The boundary between CC4B and CC5 zones is characterised by the LO of $S$. colligata, yet this event has still not been recognised here. Upwards throughout the section, the LO C. maculosus (BAFC-NP 4089), L. bollii (BAFC-NP 4093) and N. ligius (BAFCNP 4097) have been recorded and correlated to the CC5 zone.

In El Portón the LO of C. maculosus has been correlated with Paraspiticeras groeberi zone assigned to the late Hauterivian. The LO of L. bollii has been used as a reliable marker within the CC5 zone. In the Neuquén Basin, this bioevent is recorded in the upper part of the Agua de la Mula Member, in beds that are included in the Paraspiticeras groeberi ammonite zone. A complete discussion of the calcareous nannofossil biostratigraphy of the Hauterivian in the El Portón section can be found in Aguirre-Urreta et al. (2019). The compiled biostratigraphy of the section is shown Fig. 3 .

Quantitative analyses of the Agua de la Mula Member show strong variations in the composition and abundance of the calcareous nannofossil assemblages. Most of the samples present a moderate preservation of nannofloras and only two levels are barren (879 y 1475). The total abundance of nannofossils is highly variable ranging from 0.165 (1710) to 10.045 (1443) (average of 4.043) nannofossils/field of view. Additionally, the average of the species richness is 19 .

As mentioned in materials and methods, the taxa having a mean relative abundance greater than $5 \%$ such as: Watznaueria spp., Micrantholithus spp., narrow canal Nannoconus, wide canal Nannoconus and Cyclagelosphaera spp. have been considered for statistical analyses. Watznaueria spp. is the dominant taxon and its maximum abundance of $94.17 \%$ is recognised in the upper levels of the section. This genus has an average abundance of $61.69 \%$ of the total assemblage of the total section. Micrantholithus spp. exhibits abundances between $1.27 \%$ and $64.47 \%$ (mean $12.21 \%$ ). Nannoconus narrow has a mean abundance of $5.05 \%$ with peak up to $59.64 \%$ in the top of section; Nannoconus wide has maximum abundance of $14.52 \%$ and Cyclagelosphaera spp. with peak up to $53.96 \%$ (Table 1). Fig. 7 summarises the fluctuations of absolute abundance of these groups throughout the analysed section. 


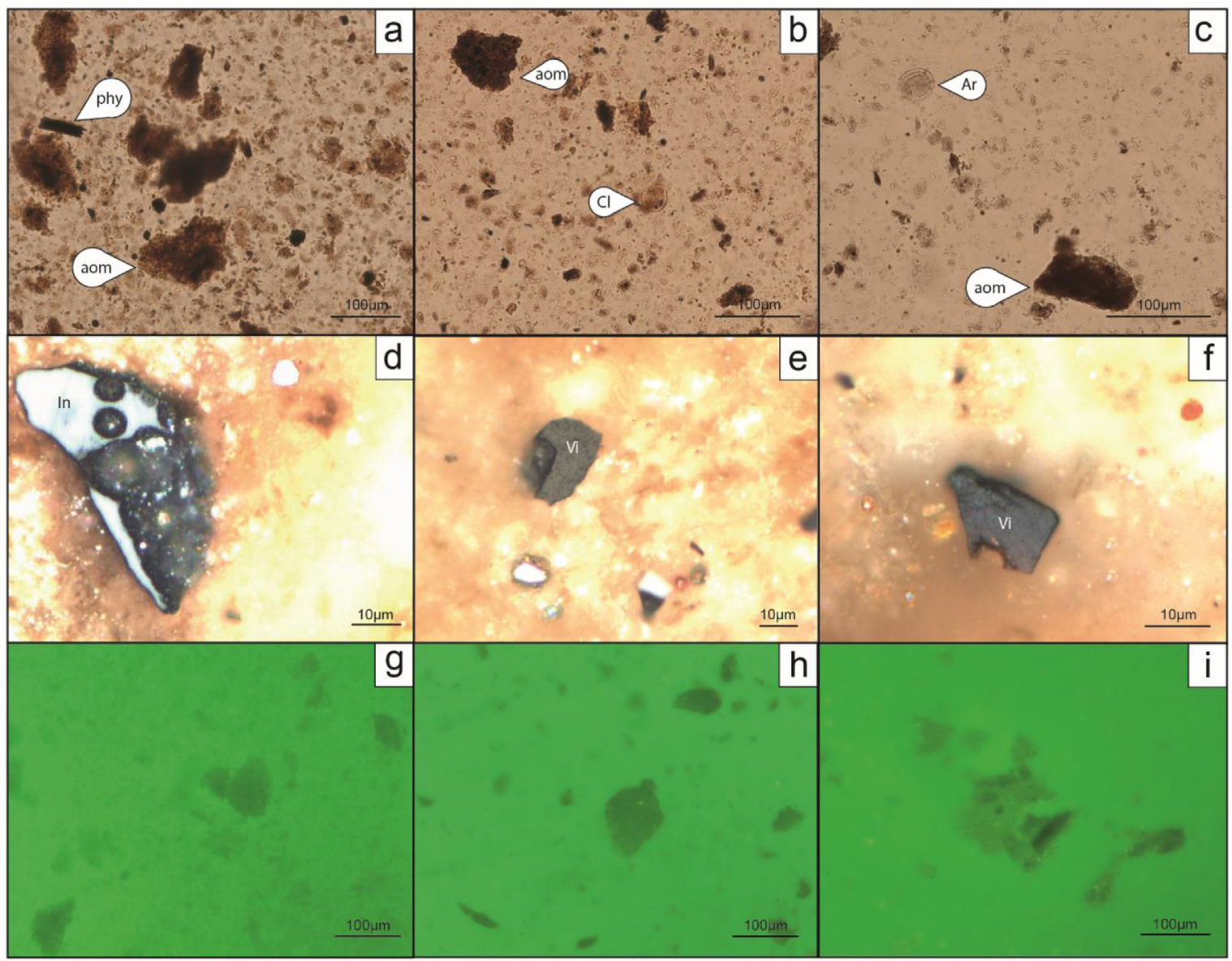

Fig. 5. Photomicrographs of samples EPJ890, EPJ1004, EPJ 1136under oil-immersion. a-c) Transmitted light. d-f) Incident white light. g-i) Fluorescence light. Aom: amorphous organic matter. Phy: phytoclasts. Cl: Cheirolepidiaceae (Classopollis sp.). Ar: Araucariaceae (Araucariacites sp.). In: Inertinite. Vi: Vitrinite.

\section{Interpretation and discussion}

In this paper, we focus on organic geochemical characteristics and calcareous nannofossils abundance and compositional changes, associated with palaeoenvironmental perturbations during the late
Hauterivian. Published data and new results will be discussed and integrated to propose a depositional model of the Agua de la Mula Member, in an attempt to understand the roles of primary productivity and variations of anoxia conditions for the organic matter preservation.

Table 3

Mineralogic composition of samples of the Agua de la Mula Member. References: vs: very scarce; s: scarce; m: moderate; a: abundant; va: very abundant; ea: extremely abundant.

\begin{tabular}{|c|c|c|c|c|c|c|c|c|c|c|c|c|}
\hline \multirow[b]{2}{*}{ Samples } & \multicolumn{8}{|c|}{ Whole Rock (Relative abundance) } & \multicolumn{4}{|c|}{ Clay Fraction (Percentage) } \\
\hline & Quartz & Plagioclase & Potassium Feldespar & Carbonate & Dolomite & Pyrite & Clay & Sulphate & $\mathrm{I} / \mathrm{S}$ & Kaolinite & Chlorite & Illite \\
\hline 1735 & A & $\mathrm{S}$ & VS & A & VS & $\mathrm{T}$ & $\mathrm{S}$ & $\mathrm{T}$ & 61.37 & 2.54 & 0.00 & 36.08 \\
\hline 1683 & VA & $\mathrm{S}$ & VS & $\mathrm{S}$ & $\mathrm{T}$ & $\mathrm{T}$ & M & $\mathrm{T}$ & 54.61 & 5.21 & 0.00 & 40.19 \\
\hline 1650 & A & VS & VS & A & $\mathrm{T}$ & $\mathrm{T}$ & $\mathrm{S}$ & $\mathrm{T}$ & 52.08 & 1.71 & 3.11 & 43.10 \\
\hline 1577 & M & $\mathrm{T}$ & VS & VA & $\mathrm{T}$ & $\mathrm{T}$ & $S$ & $\mathrm{~T}$ & 57.10 & 2.66 & 0.00 & 40.25 \\
\hline 1505 & A & VS & VS & A & $\mathrm{T}$ & $\mathrm{T}$ & $S$ & $\mathrm{~T}$ & 26.36 & 12.18 & 0.00 & 61.46 \\
\hline 1447 & A & $\mathrm{T}$ & VS & A & $\mathrm{T}$ & $\mathrm{T}$ & M & $\mathrm{T}$ & 45.62 & 1.29 & 6.44 & 46.65 \\
\hline 1396 & A & $S$ & VS & A & $\mathrm{T}$ & $\mathrm{T}$ & M & $\mathrm{T}$ & 60.35 & 2.71 & 13.26 & 23.68 \\
\hline 1316 & VA & $\mathrm{T}$ & $S$ & $S$ & $\mathrm{~T}$ & $\mathrm{~T}$ & M & $\mathrm{T}$ & 37.52 & 4.47 & 12.86 & 45.15 \\
\hline 1255 & $\mathrm{~A}$ & $\mathrm{~T}$ & VS & A & $\mathrm{T}$ & $\mathrm{T}$ & M & VS & 21.21 & 2.82 & 21.48 & 54.49 \\
\hline 1196 & M & VS & VS & A & $\mathrm{T}$ & $\mathrm{T}$ & M & $\mathrm{T}$ & 52.65 & 2.79 & 9.99 & 34.58 \\
\hline 1182 & $\mathrm{~S}$ & $\mathrm{~T}$ & VS & SA & $\mathrm{T}$ & $\mathrm{T}$ & M & $\mathrm{T}$ & 47.13 & 4.75 & 0.00 & 48.13 \\
\hline 1172 & M & VS & VS & VA & $\mathrm{T}$ & VS & $S$ & $\mathrm{~T}$ & 42.73 & 15.24 & 0.00 & 42.02 \\
\hline 1136 & M & $\mathrm{T}$ & VS & VA & VS & VS & $S$ & $\mathrm{~T}$ & 61.43 & 11.64 & 0.00 & 26.93 \\
\hline 1083 & M & VS & VS & VA & $\mathrm{T}$ & $\mathrm{T}$ & M & $\mathrm{T}$ & 52.39 & 3.18 & 0.00 & 44.43 \\
\hline 1058 & $S$ & $\mathrm{~T}$ & VS & SA & $\mathrm{T}$ & $\mathrm{T}$ & VS & $\mathrm{T}$ & 46.63 & 14.55 & 0.00 & 38.83 \\
\hline 1004 & $S$ & $\mathrm{~T}$ & VS & SA & $\mathrm{T}$ & VS & VS & $\mathrm{T}$ & 50.50 & 7.04 & 0.00 & 42.46 \\
\hline 953 & $S$ & $\mathrm{~T}$ & VS & SA & $\mathrm{T}$ & $\mathrm{T}$ & VS & $\mathrm{T}$ & 0.32 & 1.37 & 0.00 & 98.31 \\
\hline 928 & $S$ & $\mathrm{~T}$ & VS & SA & VS & $\mathrm{T}$ & $S$ & $\mathrm{~T}$ & 55.00 & 4.28 & 0.00 & 40.72 \\
\hline 890 & $\mathrm{~S}$ & $\mathrm{~T}$ & VS & SA & $\mathrm{T}$ & VS & VS & $\mathrm{T}$ & 32.24 & 0.00 & 0.00 & 67.76 \\
\hline
\end{tabular}




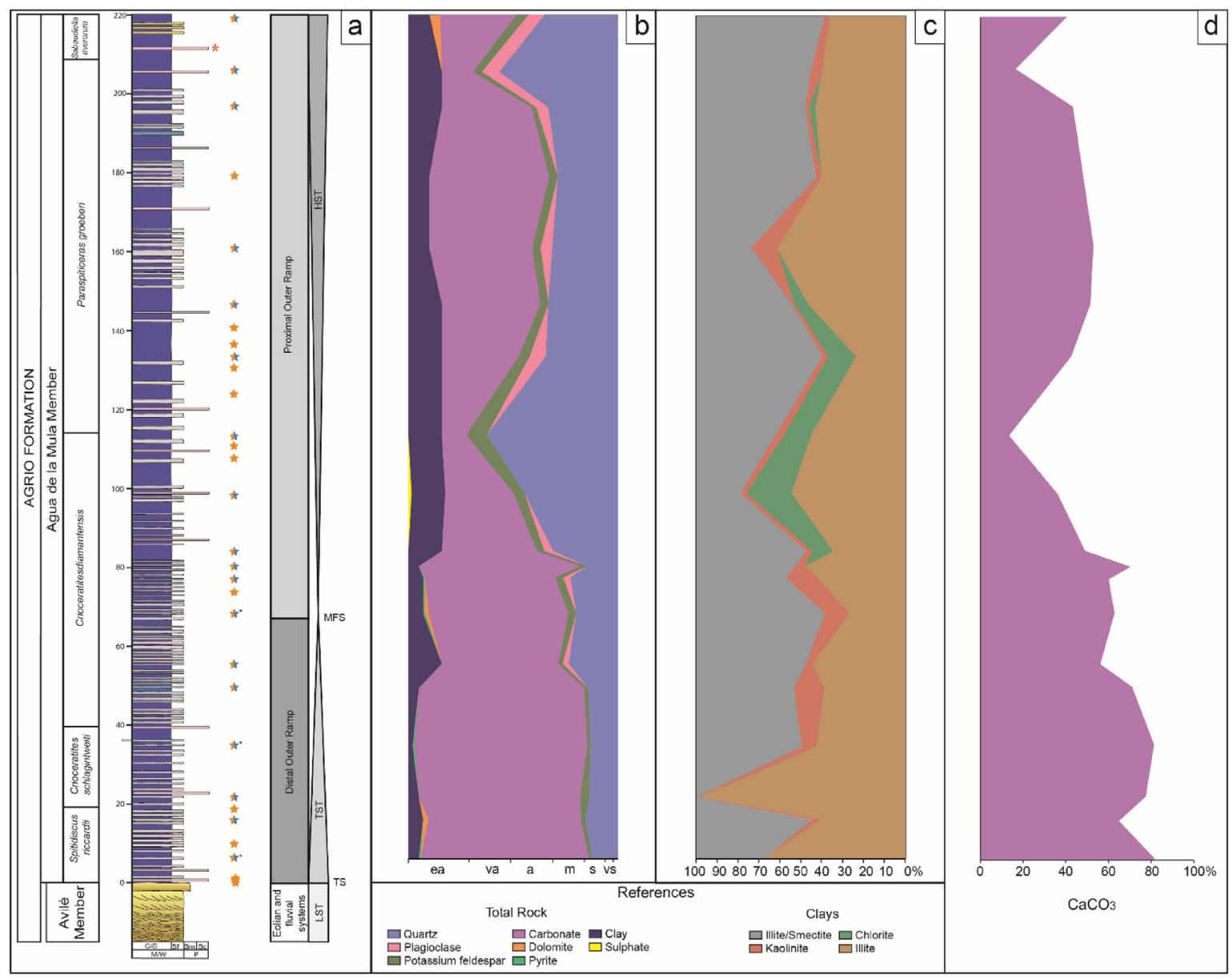

Fig. 6. a) Vertical section of the Agua de la Mula Member at the El Portón locality showing vertical distribution of: b-c) X-ray diffraction composition from whole rock and clay fraction. d) Carbonate content.

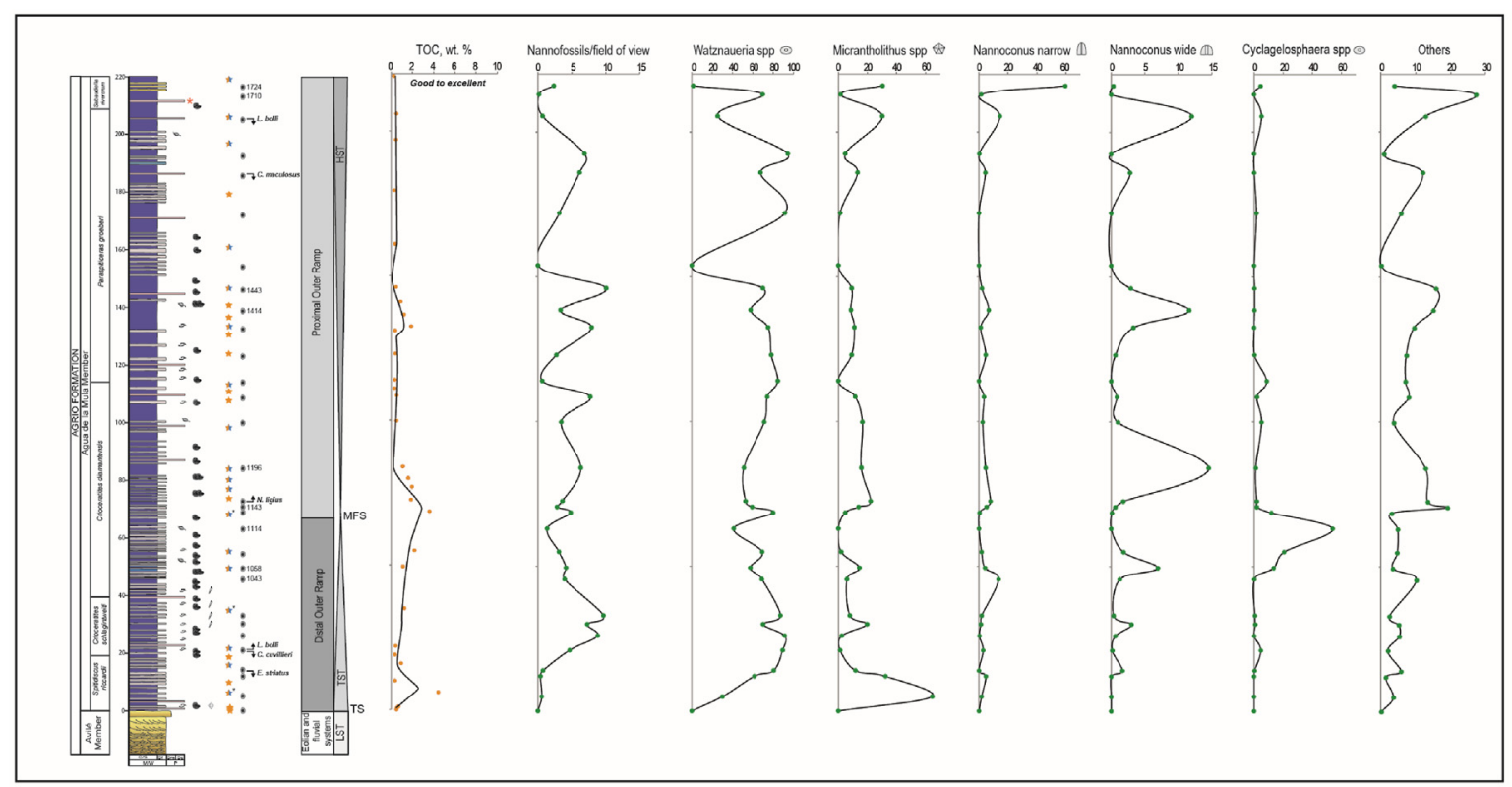

Fig. 7. Lithological column and biostratigraphy of the Late Hauterivian at the El Portón locality, plotted against TOC and nannofossils abundance percentages of Watznaueria spp., Micrantholithus spp., narrow and wide canal Nannoconus, Cyclagelosphaera spp. and "other species". 


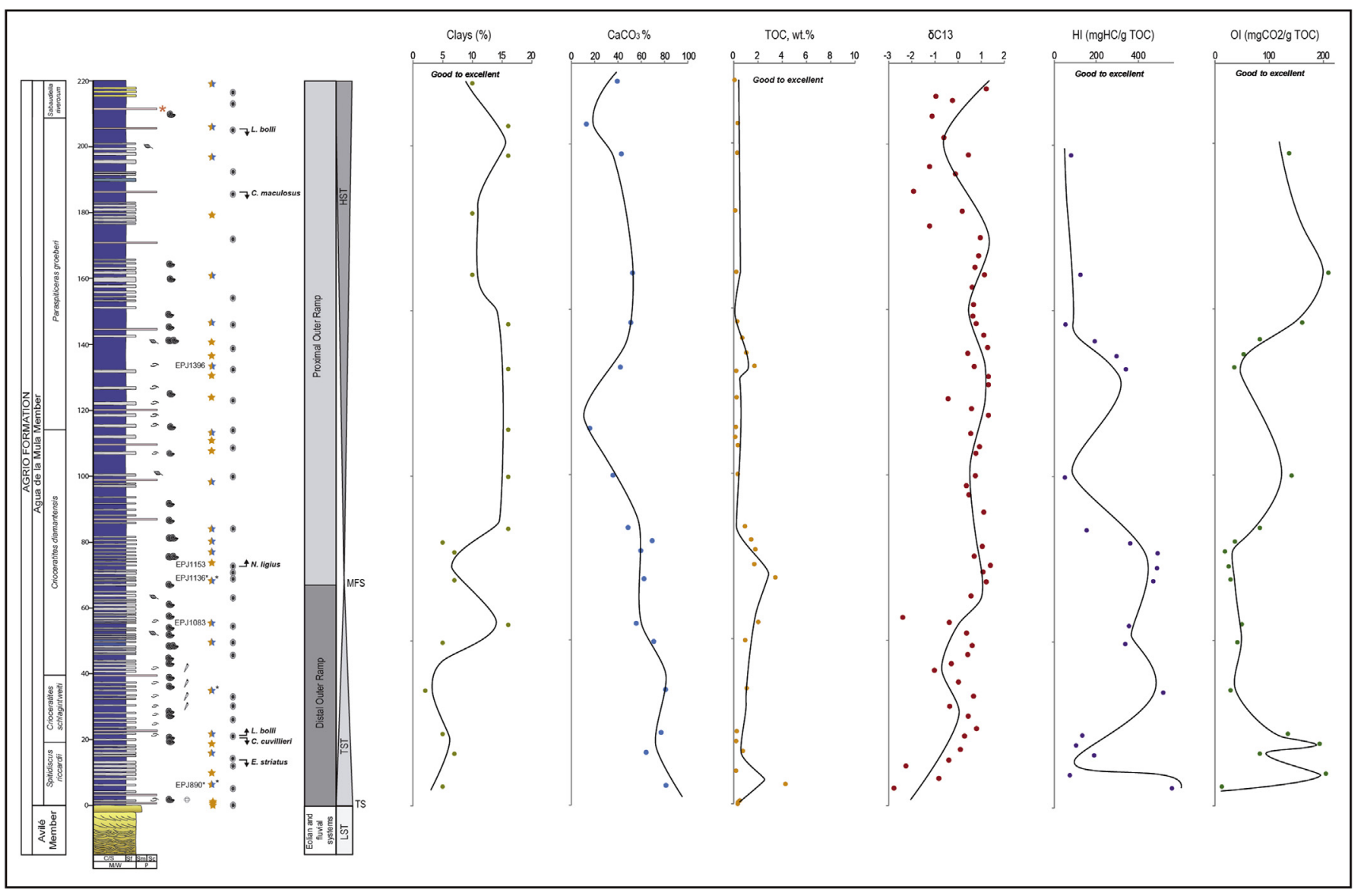

Fig. 8. Lithological column plotted against clay and carbonate content, TOC, $\delta^{13} \mathrm{C}$, HI and OI.

\subsection{Depositional system and stratigraphic architecture}

The Agua de la Mula Member constitutes an excellent example of a carbonate-siliciclastic succession characterised by a complex alternation of clay-rich hemicycles (calcareous shales and marlstones) and carbonate-rich hemicycles (mudstones/wackstones). This rhythmic bedding is the main attribute of the unit and is clearly revealed in outcrops (Sagasti, 2000). The marine strata of the Agua de la Mula Member initiates with FA1, sharply overlying the fluvial and aeolian deposits of the Avilé Member (cf. Guler et al., 2013). FA1 represent conditions of very low energy associated with the deepest part of the depositional system, replaced transitionally upwards by the more proximal deposits of FA2 (Fig. 8). This lithology arrangement is interpreted to reflect the facies evolution from a distal to a proximal outer ramp sub-environment following the homoclinal model of ramps of Burchette and Wright (1992).

Based on the general compilation of stratigraphic data elaborated by other authors (Legarreta and Uliana, 1991; Spalletti et al., 2001; Archuby et al., 2011; Guler et al., 2013) and considering the facies association analyses presented in this contribution, as well as the identification of key surfaces, a depositional sequence is recognised in the Agua de la Mula Member at the El Portón locality. In this sense, the deposition of deep marine strata of FA1 over the fluvial and aeolian deposits of the Avilé Member evidences a transgressive surface (TS) that is in concordance with the appearance of Spitidiscus riccardii ammonoid biozone.

The basal succession of the Agua de la Mula Member is represented entirely by the deepest deposits of the distal outer ramp, where the observed vertical trend corresponds to a retrogradational stacking pattern reflecting a higher rate of formation of accommodation space than the rate of carbonate production. Consequently, this part of the sedimentary succession can be defined as a transgressive system tract (TST). In turn, the highstand systems tract (HST) is recognised due to the proximal outer ramp deposits that become more common and thicker upwards, representing an upward shallowing trend. This trend reflects an aggradational stacking pattern and indicates a higher rate of sediment supply in comparison with the accommodation space formation rate. The maximum flooding surface (MFS) is defined at the base of the proximal outer ramp, as the transitional limit between FA1 and FA2 deposits, where micrite-dominated mudstones still dominate but are later rapidly replaced upwards by more proximal deposits (massive calcareous shales (Mcs) and massive marlstones (Mms) facies). This interpretation is supported by the evidence of high TOC values near this zone (samples EPJ 1083, EPJ1136, EPJ 1153).

This sequence stratigraphy framework is used here to help interpret variations in the geochemical signal and nannofossils assemblages in response to palaeonvironmental fluctuations.

\subsection{The geochemical signal of the Agua de la Mula Member marine sediments}

\subsubsection{Source rock characterization}

The changes in the organic carbon contents are noticeable along the Agua de la Mula Member in the El Portón section (Fig. 8). The highest values were registered at the base of the Spitidiscus riccardii zone (sample EPJ890: $4.43 \mathrm{wt} \%$ ) and in the middle-lower part of the Crioceratites diamantensis zone (EPJ1083: $2.19 \mathrm{wt} \%$ and EPJ1136: $3.60 \mathrm{wt}$ \%). Another interval with a relatively high TOC value (EPJ1396: $1.95 \mathrm{wt} \%)$ was recorded within the Paraspiticeras groeberi zone $(\sim 130 \mathrm{~m})$. The rest of the unit presents relatively low TOC values (0.35-1.88 w.\%). At the same El Portón section, Moore (2018) and Moore et al. (2020) documented TOC contents ranging between 0.31 
and $15.90 \mathrm{wt} \%$, where the highest concentrations belong to what she defined as source interval 4 (Spitidiscus riccardii zone) and 5 (Crioceratites diamantensis zone). Further south from the El Portón locality, other sections such as Bajada del Agrio, Agrio del Medio, Agua de la Mula, Anticlinal Pichi Mula, Cerro Rayoso and Mina San Eduardo, show TOC values ranging from 2 to $5.80 \mathrm{wt} \%$ within the Spitidiscus riccardii zone and close to $1 \mathrm{wt} \%$ at the base of the Crioceratites diamantensis zone (Tyson et al., 2005; Guler et al., 2013; Comerio et al., 2017a, 2017b). Comparing these data with the results presented here, an upward-increasing trend in the organic matter content is observed from south to north. In this sense, the more organic-rich sediments are located at the northern section of the El Portón situated in a more distal position than the other sections mentioned above (Fig. 1a). By compiling all these data, the correlations are always based on the first two intervals, while the third has not been correlated so far.

The samples of the Agua de la Mula Member plotted in the pseudo Van-Krevelen diagram (Fig. 4a) and in the kerogen quality diagram (Fig. 4b) show a wide range of organic matter type, with most of the samples dominated by kerogen Type II and II/III. In the maturity diagram (Fig. 4c) the samples present low maturity which equates with the immature to early mature oil window $\left(0.61-0.65 \% \mathrm{R}_{\mathrm{o}}\right)$, indicating that the organic matter has undergone minor thermal diagenesis. Based on palynofacies (Tyson et al., 2005; Guler et al., 2013) and pyrolysis analyses (Comerio et al., 2017a, 2017b; Moore, 2018; Moore et al., 2020), Type II/II-III kerogen was were also reported for the Spitidiscus riccardii shales and the lowermost part of the Crioceratites diamantensis zone.

Furthermore, the petrographic observations presented here confirm and support the results reported by Guler et al. (2013) from the Agrio del Medio and Bajada del Agrio sections. High proportions of marinederived amorphous organic matter (AOM) characterise the samples of the TST (Spitidiscus riccardii zone) and the lowermost part of the HST (Crioceratites diamantensis zone), which correlates with high TOC and HI values suggesting a very poorly-oxygenated environment associated with a distal outer ramp setting (Fig. 8). The rest of the Agua de la Mula Member included in the overlying HST, is dominated by terrestriallyderived components (phytoclasts). This could suggest proximity to a source of terrestrial organic matter and/or oxidizing environments in more proximal settings as it can be observed in the high OI values (Fig. 8). The presence of pollen grains assignable to the Cheirolepidiaceae (Classopollis sp.) and the Araucariaceae (Araucariacites sp.), reflects that this flora was a component of the local vegetation associated with warm and humid climate, supplied directly to the marine basin or via run off (Guler et al., 2013). Finally, the weakly to moderate fluorescence and predominantly orange to golden yellow colours, indicate that the rocks are early mature (Fig. $5 \mathrm{~g}$-i).

\subsubsection{Carbonate vs. terrigenous material and organic matter content}

As shown in Fig. 8, a change in the depositional environment from FA1 to FA2, can be observed. The position of most distal and proximal sediments could be inferred based on the shift in the carbonate content as well as in the changes of internal arrangements (TST-HST). The upward decrease in the carbonate content and increase in the total clay towards shallower settings, is indicative of dilution of calcareous material by a higher siliciclastic input as a result of sea-level lowstands and/or increasing erosion of the hinterlands. However, the carbonate content remains notoriously and considerably high throughout the section, suggesting that its production clearly prevailed from the beginning of the transgression. In the Neuquén Basin, the carbonate system produced very continuous carbonate components (skeletal remains, non-skeletal grains and carbonate mud) due to the gently inclined shelf geometry and the low amplitude sea-level fluctuations. In this type of systems, the siliciclastic material only dilutes the carbonate sediments but does not shut off the carbonate factory (Zeller et al., 2015).

The TOC contents of thermally immature sediments are a function of three interrelated factors: organic matter input, organic matter preservation and dilution by siliciclastic components (Tyson, 2005). Throughout the Agua de la Mula Member, the organic-matter enriched strata predominantly occur in the massive mudstone-wackestone facies (Mm-Mw) with minimal clay contents (Fig. 8). The enrichment could be reflecting elevated primary production in the surface waters and a good preservation enhanced by dysoxic-anoxic conditions during the deposition. This is also observable when correlating the TOC contents with HI/OI values, where high TOC correlate with high $\mathrm{HI}$ and low OI values, accordingly. In contrast to $\mathrm{Mm}-\mathrm{Mw}$, some intervals associated with calcareous shales (Mcs) (i.e: $55 \mathrm{~m}$; $132 \mathrm{~m}$ ) with the same high HI and low OI relationship, show lower TOC values probably due to dilution of organic matter by higher clastic input (Fig. 8; Table 2).

Furthermore, there is a correspondence between the $\delta^{13} \mathrm{C}_{\text {carb }}$ isotope signal presented by Aguirre-Urreta et al. (2019) for the Agua de la Mula Member and the TOC content that have been obtained in this work. As shown in Fig. 8, the carbon isotope composition of carbonates is characterised by a rapid increase on average from -1.8 to $+0.2 \%$ in the first $20 \mathrm{~m}$ of the section. Then a gradual increase to values around $+1 \%$ is observed at $70 \mathrm{~m}$, that remains quite constant until level $170 \mathrm{~m}$. The positive $\delta^{13} \mathrm{C}_{\text {carb }}$ excursions are recorded at the base of the Spitidiscus riccardii zone and near the maximum flooding surface (MFS) in the Crioceratites diamantensis zone. These excursions could be reflecting a particular carbon isotope composition of the Neuquén Basin sea-waters related to local conditions and palaeoenvironmental changes. The Neuquén Basin was a semi-restricted and gulf-shaped basin bounded in the west by a volcanic island arc, and connected temporally with open-marine waters of the Pacific Ocean through narrow passages (Howell et al., 2005). In addition, during the Late Hauterivian the Neuquén Basin was located near the transition between two climate zones, an arid belt to the north and a humid-warm temperate to the south (Sagasti, 2005; Boucot et al., 2013). The migration of these belts caused fluctuations in the environmental conditions, where a more humid regime may have risen nutrient supply from the continent towards the sea enhancing bioproductivity. The combination of low energy and stratified-waters due to the restricted basin configuration and the increased marine productivity could have favoured short periods of anoxia, reflected in the high TOC values and the positive $\delta^{13} \mathrm{C}_{\text {carb }}$ excursions.

\subsection{Calcareous nannofossils as palaeoenvironmental indicators}

Calcareous nannofossils are sensitive to environmental perturbations and the changes in their abundance and composition represent a tool to reconstruct palaeoceanographic and palaeoclimatic changes. In this sense, we record several episodes in the studied interval.

Watznaueria spp. is the most abundant taxon throughout the section, and generally, fluctuations of its abundance correlate positively with the variations in the total nannofossils assemblage abundance. High abundances indicate strong diagenetic alteration and dissolution of fragile taxa. Moderately-to well-preserved samples may suggest oligotrophic surface waters (Tremolada et al., 2009). However, other authors consider that Watznaueria spp. is a robust eutrophic taxon rather than a true oligotrophic indicator. This means that fluctuations in the percentage of abundances of this taxon probably do not represent a direct response to environmental changes, but may reflect a measure of the success of other species (Aguado et al., 2014).

High abundances of Micrantholithus are recorded at the base of the section. This group was considered as a marginal or neritic taxon and its abundance has been related to neritic factors such as reduced salinity (Roth and Bowdler, 1981; Street and Bown, 2000; Bersezio et al., 2002; Bown, 2005; Tremolada et al., 2009; Quijano et al., 2012). Furthermore, Aguado et al. (2014) also suggested that Micrantholithus spp. abundance is more related to neritic reduced salinity rather than a high or low fertility (high or low nutricline). Based on these interpretations, the particular high abundance of Micrantholithus spp. at the base of the 


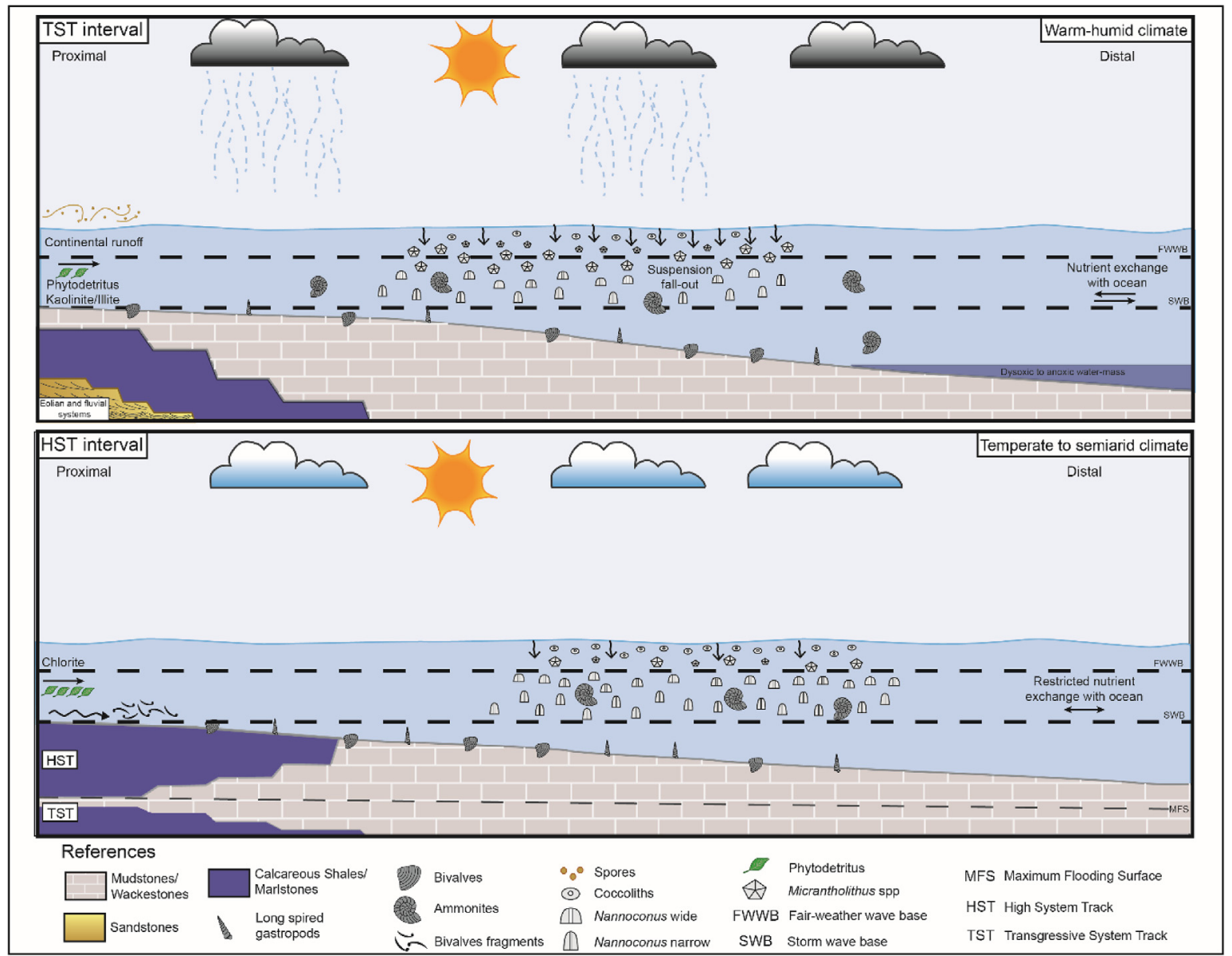

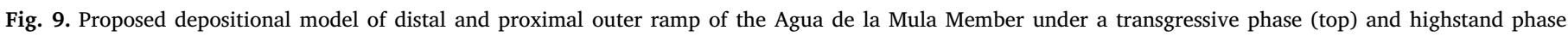
(bottom). Not to scale.

section probably suggests the flourishment of this taxon due to a lower salinity of surface waters, as the result of wetter climatic conditions and increased continental runoff. This pattern is considered of importance since it is linked to the highest TOC content registered within carbonate-rich strata (Fig. 7), demonstrating that those specific palaeoenvironmental conditions prevailed during the deposition of the Agua de la Mula Member.

At the base of the Crioceratites diamantesis zone (near the MFS) there is a short interval represented by samples 1058 to 1114 showing an increase in the abundance of the Cyclagelosphaera spp., exceeding the predominance of Watznaueria. Cyclagelosphaera is associated with marginal environments, which could be related with episodes of relative sea-level fall and more stable conditions that allowed the development of these nannofossil assemblages. Busson et al. (1992), Tribovillard et al. (1992) and Busson et al. (1993) have described extremely high abundances of $C$. margerelii characterised by low diversity and distinct variations in salinity within a restricted marine environment. In the studied section, an increase in the abundance of Cyclagelosphaera is correlated with the maximum flooding surface and associated with a high TOC content. This situation has not been registered in other sections of the basin, where this genus is recognised in facies assigned to marginal environments.

The abundances of narrow canal Nannoconus group fluctuate slowly throughout the section. However, the peaks in samples 1043 and 1724 are remarkable. Nannoconids were abundant in warm, detrital-free and possibly stratified waters, and especially the narrow canal forms, were adapted to thrive in the deep photic zone under nutrient-rich conditions (Erba, 1994). Variations in their abundance should therefore be interpreted in terms of nutricline depth: a decrease in Nannoconus spp. indicates a shallow nutricline due to high surface water fertility and vice versa (Erba, 1994, 2004; Herrle, 2003; Watkins et al., 2005; Tremolada et al., 2006; Browning and Watkins, 2008).

The wide Nannoconus group show small fluctuations in their abundances with two peaks in samples 1196 and 1414. The former correlates with a level at the base of the proximal outer ramp after the maximum flooding surface, while the latter corresponds with the lower part of Paraspiticeras groeberi ammonite zone. Nannoconids are more abundant in neritic environments, and probably inhabited the lower part of the photic zone. Aguado et al. (2014) suggest that high percentages of wide nannoconids may be indicative of higher concentration of nutrients within the uppermost part of the lower photic zone. Lower percentages of the wide Nannoconus group and relatively high abundances of Watznaueria spp. could then reflect a slightly better mixing of the upper and lower part of the photic zone (Melinte and Mutterlose, 2001).

Two additional levels are highlighted within the HST interval. In sample 1143, the maximum abundance and diversity of nannofossil associations (14 genera and 30 species) are recognised. Conversely, in sample 1679 a greater equitably is observed among the selected groups. In the Cretaceous, the increase in nannofossil diversity correlates with times of cooler climates, apparently triggering bio-provincialism and expansion of endemic taxa (Bown et al., 2004).

\subsection{Palaeoenvironmental and palaeoceanographic interpretations}

The Agua de la Mula Member shows changes in the organic matter and carbonate content, the $\delta^{13} \mathrm{C}_{\text {carb }}$ isotope excursions and the calcareous nannofossil assemblages. Based on the comparison between these variations two main intervals can be identified across the analysed unit: 


\subsubsection{The TST interval $(0-70 \mathrm{~m})$}

After the rapid flooding, deep water carbonate-bearing mudstones were deposited. Sediment accumulation was controlled by carbonate mud and carbonate shell material, and in a lesser proportion by siliciclastic components.

During this interval, enhanced rates of marine productivity may have been fueled by nutrients supply due to runoff during warm and humid conditions. The genus Watznaueria is characteristic throughout this succession as well as the acme of Micrantholithus and Cycalgelosphaera at the base of the section and near the MFS, respectively. This period of punctual enhanced primary productivity in sea water surface associated with lower oxygen availability in bottom waters, promote an oxygen minimum zone (OMZ) expansion and foster organic matter preservation. Both, the high marine productivity and/or preservation of organic matter change the inorganic carbon signal toward ${ }^{13} \mathrm{C}$ isotope enriched values (Sauvage et al., 2013; Erba, 2004 and references there in). This can be observed in the positive $\delta^{13} \mathrm{C}_{\text {carb }}$ excursions at the base of the interval and near the maximum flooding surface (between 50 and $70 \mathrm{~m}$ ), related to high organic matter content of predominantly marine composition (Type II kerogen). In addition, this interval displays an increasing content of kaolinite (between 15 and $70 \mathrm{~m}$ ), which is interpreted as an indicator of humid climate. This climatic condition is further supported by spores and pollen that have been documented (Fig. 9, Table 4).

\subsubsection{The HST interval $(70-220 \mathrm{~m})$}

In the lower highstand (LHST) deposits, after the maximum flooding surface, a distinctive carbonate-bearing pattern is still observed. The proxy trends indicate relatively high concentrations of organic matter $(>1 \%)$ in concordance with high bioproductivity and slightly increased $\delta^{13} \mathrm{C}$ values. These data could reflect similar environmental conditions in the LHST as in the TST or a time-lag effect after the MFS, where sea level was still high and anoxia prevailed.

The rest of the sequence is characterised by an overall decline in $\mathrm{CaCO}_{3}$ and an increment in siliciclastic components, probably due to an increased sedimentary dilution and/or a lower carbonate production. The continental contribution is reflected by sporadically enhanced terrestrial organic matter (Type II-III). The TOC signal remains low $(<1 \%)$, likely owing to the background sedimentation, degradation in more oxygenated conditions, and/or remineralisation during early diagenesis. Finally, primary production depicts an increase in the diversity and higher abundances of nannoconids in contrast with the TST.

The relative abundance of chlorite in this interval is noticeable. Chlorite is formed through the alteration and dissolution of volcaniclastic grains and $\mathrm{Fe}-\mathrm{Mg}$ rich minerals under temperate or dry climates (Nesbitt and Young, 1984; Thiry, 2000). Therefore, its presence can be used as a proxy to predict drier climatic conditions with reduced hydrolysis in the hinterlands. The increased chlorite input and decreased kaolinite concentration (between 80 and $160 \mathrm{~m}$ ), is attributed to an enhanced aeolian input and reduced fluvial supply. This is supported by the climatic conditions mentioned before (see section 6.2.2) during the Lower Cretaceous in the Neuquén Basin. (Fig. 9, Table 4).

\section{Concluding remarks}

1. The present study provides a multi-proxy approach combining sedimentological, geochemical and paleobiological data of the Agua de la Mula Member of the Agrio Formation. The integrated study allowed the characterization of the paleoenvironmental and palaeoceanographic changes in the Neuquén Basin during the Late Hauterivian.

2. The facies analysis of the Agua de la Mula Member allowed the identification of two facies associations. The basal FA1 represents the distal outer ramp deposits and FA2 the proximal outer ramp deposits. The FA1 represents a retrogradational stacking pattern, reflecting a higher rate of formation of accommodation space than 
the rate of carbonate supply and corresponds to the transgressive system tract (TST). The highstand system tract (HST) is recognised by the aggradational stacking pattern of the FA2 deposits, interpreted as the response to a temporary decrease in the rate of relative sea-level rise or by an increase of the sediment supply. The TST is separated from the HST by the maximum flooding surface (MFS).

3. The carbonate-bearing mudstones in the TST interval are characterised by the highest TOC content ( 4.43 and $3.60 \mathrm{wt} \%$ ) in concert with a positive shift in carbon-isotope values, reflecting enhanced bioproductivity, dysoxic-anoxic bottom waters and reduced dilution by siliciclastic material in a distal setting. The rest of the unit show relatively low TOC values (0.35-1.88 w.\%) and a major input of continental-derived particles. Most of the samples are dominated by kerogen Type II and II-III with a mixed marine and terrigenous signature. The $\mathrm{T}_{\max }$ values, the $\% \mathrm{R}_{\mathrm{o}}$ and the weak to moderate fluorescence of predominantly orange to golden yellow colours, suggest that organic material are immature to early mature.

4. The assemblage I1 is the most widespread clay assemblage throughout the succession and is reflecting the mineralogical transformation from the mixed layer illite-smectite to illite with temperature during diagenesis. The relationship 50-50\% indicates that transformations were not fully completed. Moreover, according to the difractogramas the relationship of smectite within the mixed layer illite-smectite is $50-75 \%$, which indicates that the source rock reached temperatures around $60-110^{\circ} \mathrm{C}$ and is situated within the early oil window. The presence of kaolinite and chlorite, within the assemblage I2, is indicative of different climatic conditions for the TST and HST interval, respectively. The increasing content of kaolinite in the TST interval suggests the alteration of feldspar due to humid climate, while the increased input of chlorite in the HST interval indicates alteration of volcaniclastic Fe-Mg rich grains owing to drier climatic conditions with reduce hydrolysis in the hinterlands.

5. The quantitative study of calcareous nannofossils allowed the recognition of changes in the composition and abundance of their assemblages. These changes have been compared with other proxies (TOC and $\delta^{13} \mathrm{C}$ ) that enabled the differentiation of intervals with decreased salinity and enrichment in nutrients from others more indicative of water column stratification.

6. The primary productivity may have been boosted under warm and humid conditions, likely owing to the global climate and/or the local latitudinal migration of climatic belts during the Late Hauterivian.

7. The variation of clay mineralogy from kaolinite-rich to chlorite-rich sediments further supports our interpretation that climate changes occurred.

8. The multidisciplinary method applied in this work, highlights the necessity of using different proxies to obtain a more comprehensive picture of the environmental context that existed in the Neuquén Basin. In future works, major and trace-metal concentration (Al, Th, $\mathrm{Ti}, \mathrm{Zr}, \mathrm{Cu}, \mathrm{Ni}, \mathrm{P}, \mathrm{U}, \mathrm{V}, \mathrm{Mn}, \mathrm{Fe}$ ) should be quantified in order to better interpret the palaeoclimatic changes, palaeoproductivity in the bottom waters and the associated redox conditions. Moreover, a higher-resolution and more regional organic geochemistry study could assist in refining the interpretations and improve the understanding of the Agua de la Mula Member source rock.

\section{CRediT authorship contribution statement}

Marina Lescano: Investigation, Writing - original draft. Andrea Lorena Odino-Barreto: Investigation, Writing - original draft. Débora Campetella: Visualization. Maísa Tunik: Funding acquisition, Supervision. Fabián Brea: Investigation, Resources. Georgina Erra: Investigation, Resources. Beatriz Aguirre-Urreta: Funding acquisition, Writing - review \& editing. Mathieu Martinez: Writing - review \& editing.

\section{Declaration of competing interest}

The authors declare that they have no known competing financial interests or personal relationships that could have appeared to influence the work reported in this paper.

\section{Acknowledgments}

We wish to acknowledge the financial support from UNRN (PI: 40A698), and CONICET (PUE: 0031CO) and IDEAN (Instituto de Estudios Andinos "Don Pablo Groeber, CONICET-UBA) which made this project possible and supported the research activities, as part of the Ph.D thesis of the first author. We specially thank Lucas Lothari and Diego Pino for their help in the field. Sincere thanks are extended to Martín Parada for his technical assistance and XRD analyses. A special note of thank goes to Dr. Juan Ponce for his support and interesting discussions. We are grateful to $\mathrm{H}$. Karg for his constructive comments and suggestions that enhanced the quality of this manuscript. This is contribution R-323 of the Instituto de Estudios Andinos "Don Pablo Groeber".

\section{Appendix A. Supplementary data}

Supplementary data to this article can be found online at https:// doi.org/10.1016/j.marpetgeo.2020.104469.

\section{References}

Aguado, R., Company, M., O'dogherty, L., Sandoval, J., Tavera, J.M., 2014. Late Hauterivian-Early Barremian calcareous nannofossil biostratigraphy, palaeoceanography, and stable isotope record in the Subbetic domain (southern Spain). Cretac. Res. 49, 105-124.

Aguirre-Urreta, M.B., 1989. The cretaceous decapod Crustacea of Argentina and the antarctic peninsula. Palaeontology 32, 499-552.

Aguirre-Urreta, M.B., 2003. Early cretaceous decapod Crustacea from the Neuquén Basin, west-central Argentina. Contrib. Zool. 72, 79-81.

Aguirre-Urreta, M.B., Rawson, P.F., 1997. The ammonite sequence in the Agrio Formation (lower cretaceous), Neuquén Basin, Argentina. Geol. Mag. 134, 449-458.

Aguirre-Urreta, M.B., Concheyro, G.A., Lorenzo, M., Ottone, E.G., Rawson, P.F., 1999. Advances in biostratigraphy of the Agrio Formation (lower cretaceous) of the Neuquén Basin, Argentina: ammonites, palynomorphs and calcareous nannofossils. Palaeogeogr. Palaeoclimatol. Palaeoecol. 150, 33-47.

Aguirre-Urreta, M.B., Rawson, P.F., Concheyro, G.A., Bown, P.R., Ottone, E.G., 2005. Lower cretaceous (Berriasian-Aptian) biostratigraphy of the Neuquén Basin. In: Veiga, G., Spalletti, L., Howell, J.A., Schwarz, E. (Eds.), The Neuquén Basin: A Case Study in Sequence Stratigraphy and Basin Dynamics. vol. 252. Geological Society of London, Special Publication, pp. 57-81.

Aguirre-Urreta, M.B., Casadío, S., Cichowolski, M., Lazo, D.G., Rodríguez, D., 2008. Afinidades paleobiogeográficas de los invertebrados cretácicos de la cuenca Neuquina. Ameghiniana 45, 593-613.

Aguirre-Urreta, B., Lazo, D.G., Griffin, M., Vennari, V., Parras, A.M., Cataldo, C., Garberoglio, R., Luci, L., 2011. Megainvertebrados del Cretácico y su importancia bioestratigráfica. In: Relatorio del XVIII Congreso Geológico Argentino. Geología de los Recursos Naturales de la Provincia de Neuquén, pp. 465-488 (Neuquén).

Aguirre-Urreta, B., Lescano, M., Schmitz, M.D., Tunik, M., Concheyro, A., Rawson, P.F., Ramos, V.A., 2015. Filling the gap: new precise Early Cretaceous radioisotopic ages from the Andes. Geol. Mag. 152, 557-564.

Aguirre-Urreta, B., Martinez, M., Schmitz, M., Lescano, M., Omarini, J., Tunik, M., Kuhnert, H., Concheyro, A., Rawson, P.F., Ramos, V.A., Reboulet, S., Noclin, N. Frederichs, T., Nickl, A.-L., Pälike, H., 2019. Interhemispheric radio-astrochronological calibration of the time scales from the andean and the tethyan areas in the valanginian-hauterivian (early cretaceous). Gondwana Res. 70, 104-132. https:// doi.org/10.1016/j.gr.2019.01.006.

Applegate, J., Bergen, J., 1988. Cretaceous calcareous nannofossil biostratigraphy of sediments recovered from the Galicia Margin, ODP Leg 103. In: In: Boillot, G., Winterer, E.L., Meyer, A.W. (Eds.), Proceedings of the Ocean Drilling Project, vol. 103. Scientific Results, pp. 293-348.

Archuby, F.M., Wilmsen, M., Leanza, H.A., 2011. Integrated stratigraphy of the upper hauterivian to lower barremian Agua de la Mula member of the Agrio Formation, Neuquén Basin, Argentina. Acta Geol. Pol. 61, 1-26.

Ballent, S., Carignano, A.P., Iglesias, A., Poiré, D.G., 2011. Microfósiles calcáreos no marinos y semillas de la Formación Piedra Clavada (Albiano) en su área tipo, provincia de Santa Cruz, Argentina. Ameghiniana 48 (4), 541-555.

Behar, F., Beaumont, V., De, B., Penteado, H.L., 2001. Rock-eval 6 technology: performances and developments oil and gas science and technology. Rev. IFP. 56 (2), $111-134$.

Bersezio, R., Barbieri, P., Mozzi, R., 2002. Redeposited limestones in the upper cretaceous succession of the helvetic argentera Massif at the Italy-France border. Eclogae Geol. 
Helv. 95, 15-30.

Boucot, A.J., Xu, C., Morley, R.J., Scotese, C.R., 2013. Phanerozoic paleoclimate: an atlas of lithologic indicators of climate. In: In: Nichols, G.J., Ricketts, B. (Eds.), Phanerozoic Paleoclimate: Concepts in Sedimentology and Paleontology, vol. 11. SEPM, Tulsa, pp. 1-18.

Biscaye, P.E., 1965. Mineralogy and sedimentation of recent deep-sea clay in the Atlantic Ocean and adjacent seas and oceans. Geol. Soc. Am. Bull. 76, 803-832.

Bown, P.R., 2005. Palaeogene calcareous nannofossils from the kilwa and lindi areas of coastal Tanzania (Tanzania drilling project 2003-4). J. Nannoplankt. Res. 27, 21-95.

Bown, P.R., Young, J.R., 1997. Mesozoic calcareous nannoplankton classification. J. Nannoplankt. Res. 19, 21-36.

Bown, P.R., Lees, J.A., Young, J.R., 2004. Calcareous nannoplankton evolution and diversity through time. In: Thierstein, H.R., Young, J.R. (Eds.), Coccolithophores. From Molecular Processes to Global Impact. Springer-Verlag, Berlin, pp. 481-508.

Browning, E.L., Watkins, D.K., 2008. Elevated primary productivity of calcareous nannoplankton associated with ocean anoxic event $1 \mathrm{~b}$ during the Aptian/Albian transition (Early Cretaceous). Paleoceanography 23, PA2213. https://doi.org/10.1029/ 2007PA001413.

Brindley, G.W., 1961. Experimental methods. In: Brown, G. (Ed.), The X-Ray Identification and Crystal Structure of Clay Minerals. London Mineralogical Society, pp. 1-50.

Brown, G., 1980. Tables for the determination of $\mathrm{d}$ in $\AA$ from $2 \theta$ for the Ka and $\mathrm{K} \beta$ radiations of cooper, cobalt and iron. In: Brindley, G.W., Brown, G. (Eds.), Crystal Structures of Clay Minerals and Their X-Ray Identification. London Mineralogical Society, pp. 439-475 Monograph 5.

Burchette, T.P., Wright, V.P., 1992. Carbonate ramp depositional systems. Sediment. Geol. 79, 3-57.

Busson, G., Noël, D., Cornée, A., 1992. Les coccolithes en "boutons de manchette" et la genèse des calcaires lithographiques du jurassique supérieur. Rev. Paleobiol. 11, 255-271.

Busson, G., Noël, D., Contini, D., Mangin, A.M., Cornée, A., Hantzpergue, P., 1993. Omniprésence de coccolithes dans des calcaires lagunaires du jurassique moyen et supérieur de France. Bull. Cent. Rech. Explor.-Prod. Elf-Aquitaine 17 (1), 291-301.

Carvajal-Ortiz, H., Gentzis, T., 2015. Critical considerations when assessing hydrocarbon plays using Rock-Eval pyrolysis and organic petrology data: data quality revisited. Int. J. Coal Geol. 152, 113-122. https://doi.org/10.1016/j.coal.2015.06.001.

Cichowolski, M., Lazo, D.G., 2000. Lower cretaceous marine reptiles from Argentina. In: $31^{\circ}$ International Geological Congress, CD- rom. Abstracts (Río de Janeiro).

Clementz, D.M., Demaison, G.J., Daly, A.R., 1979. Well site geochemistry by programmed pyrolysis. Offshore Technol. Conf. Proc. OTC 3410 (1), 365-470.

Comerio, M., Fernández, D.E., Heredia, A., Pazos, P.J., 2017a. Análisis sedimentológico de facies de rampa externa: La Formación Agrio (Cretácico Inferior), en el sector central de la Cuenca Neuquina, Argentina. In: XX Congreso Geológico Argentino. Actas Sesión Técnica 7: Sedimentología y Petrografía de Rocas Sedimentarias, pp. 10-11 (San Miguel de Tucumán).

Comerio, M., Fernández, D.E., Pazos, P.J., 2017b. Sedimentological and ichnological characterization of muddy storm related deposits: the upper Hauterivian ramp of the Agrio Formation in the Neuquén Basin, Argentina. Cretac. Res. 85, 78-94. https:// doi.org/10.1016/j.cretres.2017.11.024.

Concheyro, A., Lescano, M., Carames, A., Ballent, S., 2009. Micropaleontología de la Formación Agrio (Cretácico Inferior) en distintos sectores de la cuenca Neuquina. Rev. Asoc. Geol. Argent. 65, 342-361.

Cruz, C.E., Villar, H.J., Muñoz, G.N., 1996. Los sistemas petroleros del Grupo Mendoza en la fosa de Chos Malal. Cuenca Neuquina, Argentina. In: XIII Congreso Geológico Argentino y III Congreso de Exploración de Hidrocarburos. Actas, pp. 45-60 (Buenos Aires).

Cruz, C.E., Kozlowski, E., Villar, H.J., 1998. Agrio (Neocomian) petroleum systems: main target in the Neuquén Basin thrust belt, Argentina. In: Mello, M.R., Yilmaz, P.O. (Eds.), AAPG International Conference and Exhibition. Extended Abstracts, pp. 670-671 (Río de Janeiro).

Edwards, A., 1963. A preparation technique for calcareous nannoplankton. Micropaleontology 9, 103-104.

Erba, E., 1994. Nannofossils and superplumes: the early Aptian "nannoconid crisis". Paleoceanography 9, 483-501.

Erba, E., 2004. Calcareous nannofossils and Mesozoic oceanic anoxic events. Mar. Micropaleontol. 52, 85-106.

Erba, E., Bartolini, A., Larson, R.L., 2004. Valanginian Weissert oceanic anoxic event. Geology 32, 149-152.

Espitalié, J., Deroo, J., Marquis, F., 1985. La pyrolyse Rock-Eval et ses applications. Deuxième partie. Rev. Inst. Fr. Petrol 40, 755-784.

Espitalié, J., Deroo, J., Marquis, F., 1986. La pyrolyse Rock-Eval et ses applications. Troisième partie. Rev. Inst. Fr. Petrol 41, 73-89.

Fantín, M., González, R., 2014. Primeros Pasos en la Evaluación de Vaca Muerta como Reservorio No-Convencional en el Bloque El Trapial. In: IX Congreso de Exploración y Desarrollo de Hidrocarburos. Simposio de Recursos No Convencionales: Ampliando el Horizonte Energático, pp. 631-652 (Mendoza).

Franzese, J.R., Spalletti, L.A., Gómez Pérez, I., Macdonald, D., 2003. Tectonic and paleoenviromental evolution of Mesozoic sedimentary basins along the Andean foothills of Argentina $\left(32^{\circ}-54^{\circ} \mathrm{S}\right)$. J. S. Am. Earth Sci. 16, 81-90.

González Tomassini, F., Kietzmann, D.A., Fantín, M.A., Crousse, L.A., Reijenstein, H.M. 2015. Estratigrafía y análisis de facies de la Formación Vaca Muerta en el área de El Trapial. Petrotecnia 2, 78-89.

Guler, M.V., Lazo, D.G., Pazos, P.J., Borel, C.M., Ottone, E.G., Tyson, R.V., Cesaretti Aguirre-Ureta, M.B., 2013. Palynofacies analysis and palynology of the Agua de la Mula member (Agrio Formation) in a sequence stratigraphy framework, lower cretaceous, Neuquén Basin, Argentina. Cretac. Res. 41, 65-81.
Gulisano, C.A., Gutiérrez Pleimling, A., 1988. Depósitos eólicos del Miembro Avilé (Formación Agrio, Cretácico inferior) en el norte del Neuquén, Argentina. Segunda Reunión Argentina de Sedimentología, Actas, pp. 120-124.

Gulisano, C.A., Gutiérrez Pleimling, A., 1995. Field Guide: The Jurassic of the Neuquén Basin. a) Neuquén Province. Secretaría de Minería de la Nación (Publicación N 158 ) y Asociación Geológica Argentina Serie (E) 2. pp. 111 Buenos Aires.

Groeber, P., 1953. Ándico, in: Geografía de la República Argentina. Sociedad Argentina Estudios Geográficos GAEA 2 (1), 349-354.

Hart, B.S., Steen, A.S., 2015. Programmed pyrolysis (Rock-Eval) data and shale paleoenvironmental analyses: a review. Interpretation 3 (1), SH41-SH58.

Herrle, J.O., 2003. Reconstructing nutricline dynamics of mid-Cretaceous oceans: evidence from calcareous nannofossils from the Niveau Paquier black shale (SE France). Mar. Micropaleontol. 47, 307-321.

Howell, J.A., Schwarz, E., Spalletti, L.A., Veiga, G.D., 2005. The Neuquén Basin: an overview. In: In: Veiga, G.D., Spalletti, L.A., Howell, J.A., Schwarz, E. (Eds.), The Neuquén Basin, Argentina: A Case Study in Sequence Stratigraphy and Basin Dynamics, vol. 252. Geological Society of London, Special Publications, pp. 1-14.

Instituto Argentino del Petróleo y Gas (IAPG), 2019. Producción de Petróleo y Gas por Cuenca. http://www.iapg.org.ar/suplemento/Agosto2019/ProduccionPorCuenca. html, Accessed date: 21 November 2019.

Jarvie, D.M., 1991. Total organic carbon (TOC) analysis. In: Merril, R.K. (Ed.), Source and Migration Processes and Evaluation Techniques. AAPG Treatise of Petroleum Geology, Tulsa, pp. 113-118.

Kessels, K., Mutterlose, J., Ruffell, A., 2003. Calcareous nannofossils from Late Jurassic sediments of the Volga Basin (Russian Platform): evidence for productivity controlled black shale deposition. Int. J. Earth Sci. 92, 743-757.

Kessels, K., Mutterlose, J., Michalzik, D., 2006. Early Cretaceous (ValanginianHauterivian) calcareous nannofossils of the northern hemisphere: a key group for the understanding of Cretaceous climate. Lethaia 39, 157-172.

Kietzmann, D.A., Palma, R.M., Riccardi, A.C., Martín-Chivelet, J., López-Gómez, J., 2014 Sedimentology and sequence stratigraphy of a Tithonian-Valanginian carbonate ramp (Vaca Muerta Formation): a misunderstood exceptional source rock in the Southern Mendoza area of the Neuquén Basin, Argentina. Sediment. Geol. 302, 64-86.

Kozlowski, E., Cruz, C., Sylwan, C.A., 1996. Geología estructural de la zona de Chos Malal. Cuenca Neuquina, Argentina. In: XIII Congreso Geológico Argentino y Congreso de III Exploración de Hidrocarburos. Actas, pp. 15-26 (Buenos Aires).

Kozlowski, E., Cruz, C., Sylwan, C., 1998. Modelo exploratorio en la faja corrida de la Cuenca Neuquina, Argentina. vol. 55. Boletín de Informaciones Petroleras, pp. 4-23.

Lazo, D., Cichowolski, M., Rodriguez, D., Aguirre-Urreta, M.B., 2005. Lithofacies, palaeoecology and palaeoenvironments of the Agrio Formation, lower cretaceous of the Neuquén Basin, Argentina. In: In: Veiga, G.D., Spalletti, L.A., Howell, J.A., Schwarz, E. (Eds.), The Neuquén Basin: A Case Study in Sequence Stratigraphy and Basin Dynamics, vol. 252. The Geological Society, Special Publication, pp. 295-315.

Leanza, H.A., Hugo, C.A., 2001. Cretaceous red beds from southern Neuquén Basin (Argentina): age, distribution and stratigraphic discontinuities. In: VII International Symposium on Mesozoic Terrestrial Ecosystems. Asociación Paleontológica Argentina, Publicación Especial, vol. 7. pp. 117-122 (Buenos Aires).

Leanza, H.A., Hugo, C.A., Repol, D., 2001. Hoja Geológica 3969-I- Zapala, provincia del Neuquén. Servicio Geológico Minero Argentino, vol. 275. Instituto de Geología y Recursos Minerales. Boletín, Buenos Aires, pp. 128.

Legarreta, L., Uliana, M.A., 1991. Jurassic-Cretaceous marine oscillations and geometry of back arc basin fill, central Argentine Andes. Sea level changes at active plate margins: process and product. In: In: Macdonald, D.I.M. (Ed.), Sea Level Changes at Active Plate Margins: Process and Product, vol. 12. International Association of Sedimentologists, Special Publication, pp. 429-450.

Legarreta, L., Villar, H., 2012. Las facies generadoras de hidrocarburos de la Cuenca Neuquina. Petrotecnia 8, 14-39.

Legarreta, L., Villar, H., Laffitte, G.A., Cruz, C., Vergani, G., 2005. Cuenca Neuquina: balance de masa enfocado a la evaluación del potential exploratorio de los distritos productivos y de las zonas no productivas. In: VI Congreso de Exploración y Desarrollo de Hidrocarburos. Instituto Argentino del Petróleo y del Gas. Actas, pp. 233-250.

Lescano, M., Concheyro, A., 2009. Nanofósiles calcáreos de la Formación Agrio (Cretácico Inferior) en el sector sudoccidental de la Cuenca Neuquina, Argentina. Ameghiniana 46, 73-94.

Lescano, M., Concheyro, A., 2014. Nanocónidos del Grupo Mendoza (Cretácico Inferior) en la Provincia del Neuquén, República Argentina: taxonomía, cronoestratigrafía e implicancias paleogeográficas. Ameghiniana 51, 466-499.

Macquaker, J.H.S., Adams, A.E., 2003. Maximizing information from fine grained sediments: an inclusive nomenclature for mudstones. J. Sediment. Res. 73, 735-744.

Melinte, C.M., Mutterlose, J., 2001. A Valanginian (Early Cretaceous) boreal nannoplankton excursion in sections from Romania. Mar. Micropalaeontol. 43 (1-2), 1-25.

Moore, D., Reynolds, R., 1989. X-Ray Diffraction and the Identification and Analysis of Clay Minerals. pp. 332 Oxford, New York.

Moore, S.A., 2018. Integrated Depositional Model and Hydrocarbon Potential of Distal Ramp Deposits, Agrio Formation, Neuquén Basin. M.S. thesis. University of Utah, Argentina, pp. 105.

Moore, S.A., Birgenheier, L.P., Greb, M.D., Minisini, D., Tunik, M., Omarini, J., 2020. Facies heterogeneity and source rock potential of carbonate mudstone-dominated distal ramp deposits, Agrio Formation, Neuquén Basin, Argentina. J. Sediment. Res. 90, 533-560. https://doi.org/10.2110/jsr.2020.25.

Nesbitt, H.W., Young, G.M., 1984. Prediction of some weathering of basalts. Am. J. Sci. 292, 740-770.

Peters, K.E., 1986. Guidelines for evaluating petroleum source rock using programmed pyrolysis. AAPG (Am. Assoc. Pet. Geol.) Bull. 70, 318-329.

Peters, K.E., Nelson, D., 1992. REESA - an expert system for geochemical logging of wells. 
AAPG Annu. Meeting Abstracts, 103.

Peters, K.E., Casa, M.R., 1994. Applied source rock geochemistry. In: Magoon, L.B., Dow, W.G. (Eds.), The Petroleum System from Source to Trap. AAPG Memoir 60, pp. 93-120.

Quijano, M.L., Castro, J.M., Pancost, R.D., Gea, G.A., Najarro, M., Aguado, R., Rosales, I., Martín-Chivelet, J., 2012. Organic geochemistry, stable isotopes, and facies analysis of the Early Aptian OAE - new records from Spain (Western Tethys). Palaeogeogr. Palaeoclimatol. Palaeoecol. 365-366, 276-293.

Riecker, R.E., 1962. Hydrocarbon fluorescence and migration of petroleum. Am. Assoc. Petrol. Geol. 46, 60-75.

Rojas Vera, E.A., Mescua, J., Folguera, A., Becker, T.P., Sagripanti, L., Fennell, L., Orts, D., Ramos, V.A., 2015. Evolution of the Chos Malal and Agrio fold and thrust belts, Andes of Neuquén: insights from structural analysis and apatite fission track dating. J. S. Am. Earth Sci. 64, 418-433.

Roth, P.H., Bowdler, J.L., 1981. Middle Cretaceous calcareous nannoplankton biogeography and oceanography of the Atlantic Ocean. In: In: Warme, J.E., Douglas, R.G., Winterer, E.L. (Eds.), The Deep Sea Drilling Project: A Decade of Progress, vol. 32. SEPM, Special Publication, pp. 517-546.

Rutledge, D., Bown, P., 1996. New names for old: taxonomic classification of some Early Cretaceous Nannofossil marker species. J. Nannoplankt. Res. 18, 53-59.

Sagasti, G., 2000. La sucesión rítmica de la Formación Agrio (Cretácico Inferior) en el sur de la Provincia de Mendoza y su posible vinculación con ciclos de Milankovitch. Revista de la Asociación Argentina de Sedimentología 7, 1-22.

Sagasti, G., 2002. Estudio sedimentológico y de estratigrafía secuencial de las sedimentitas carbonáticas de la Formación Agrio (Cretácico Inferior), en el sector surmendocino de la cuenca Neuquina, República Argentina (PhD thesis). Universidad Nacional de la Plata, Buenos Aires, pp. 280.

Sagasti, G., 2005. Hemipelagic record of orbitally-induced dilution cycles in Lower Cretaceous sediments of the Neuquén Basin. In: In: Veiga, G.D., Spalletti, L.A., Howell, J.A., Schwarz, E. (Eds.), The Neuquén Basin: A Case Study in Sequence Stratigraphy and Basin Dynamics, vol. 252. The Geological Society, Special Publication, pp. 231-250.

Sauvage, L., Riquier, L., Thomazo, C., Baudin, F., Martinez, M., 2013. The late Hauterivian Faraoni "Oceanic Anoxic Event" at Río Argos (southern Spain): An assessment on the level of oxygen depletion. Chem. Geol. 340, 77-90.

Sissingh, W., 1977. Biostratigraphy of Cretaceous calcareous nannoplankton. Geol. Mijnbouw 56, 37-65.

Spalletti, L.A., Poiré, D.G., Schwarz, E., Veiga, G.D., 2001. Sedimentologic and sequence stratigraphic model of a Neocomian marine carbonate-siliciclastic ramp: Neuquén Basin, Argentina. J. S. Am. Earth Sci. 14, 609-624.

Spalletti, L.A., Veiga, G.D., Schwarz, E., 2011. La Formación Agrio (Cretácico Temprano) en la Cuenca Neuquina. In: Leanza, H.A., Arregui, C., Carbone, O., Danieli, J.C., Vallés, J.M. (Eds.), Relatorio Geología y Recursos Naturales de la provincia del Neuquén. Asociación Geológica Argentina, Buenos Aires, pp. 145-160.

Street, C., Bown, P.R., 2000. Palaeobiogeography of early cretaceous (BerriasianBarremian) calcareous nannoplankton. Mar. Micropaleontol. 39, 265-291.

Thiry, M., 2000. Palaeoclimatic interpretation of clay minerals in marine deposits: an outlook from the continental origin. Earth Sci. Rev. 49, 201-221.

Tissot, B.P., 1984. Recent advances in petroleum geochemistry applied to hydrocarbon exploration. Am. Assoc. Petrol. Geol. Bull. 68 (5), 545-563.

Tremolada, F., Bornemann, A., Bralower, T., Koeberl, C., van de Schootbrugge, B., 2006. Paleoceanographic changes across the Jurassic/Cretaceous Boundary: the calcareous phytoplankton response. Earth Planet Sci. Lett. 241, 361-371.

Tremolada, F., Erba, E., de Bernardi, B., Cecca, F., 2009. Calcareous nannofossil fluctuations during the Late Hauterivian in the Cismon core (Venetian Alps, northeastern Italy) and in selected sections of the Umbria-Marche basin (central Italy): paleoceanographic implications of the Faraoni level. Cretac. Res. 30, 505-514.

Tribovillard, N.P., Gorin, G.E., Belin, S., Hopfgartner, G., Pichon, R., 1992. Organic-rich biolaminated facies from a Kimmeridgian lagoonal environment in the French Southern Jura mountains: a way of estimating accumulation rate variations. Palaeogeogr. Palaeoclimatol. Palaeoecol. 99, 163-177.

Tyson, R.V., 1995. Sedimentary Organic Matter. Organic Facies and Palynofacies. Chapman and Hall, London.

Tyson, R.V., 2005. The "productivity versus preservation" controversy: cause, Flaws, and resolution. In: In: Harris, N.B. (Ed.), The Deposition of Organic-Carbon-Rich Sediments: Models, Mechanisms, and Consequences, vol. 82. SEPM, Special Publication, pp. 17-33.

Tyson, R.V., Esherwood, P., Pattison, K.A., 2005. Organic facies variations in the Valanginian-mid-Hauterivian interval of the Agrio Formation (Chos Malal area, Neuquén, Argentina): local significance and global context. In: In: Veiga, G.D., Spalletti, L.A., Howell, J.A., Schwarz, E. (Eds.), The Neuquén Basin, Argentina: A Case Study in Sequence Stratigraphy and Basin Dynamics, vol. 252. Geological Society of London, Special Publications, pp. 251-266.

Uliana, M.A., Legarreta, L., 1993. Hydrocarbon habitat in a triassic to cretaceous subandean setting: Neuquén Basin, Argentina. J. Petrol. Geol. 16, 397-420.

Uliana, M.A., Legarreta, L., Laffitte, G.A., Villar, H., 1999. Estratigrafía y geoquímica de las facies generadoras de hidrocarburos en las cuencas petrolíferas de Argentina. IV Congreso de Exploración y Desarrollo de Hidrocarburos. Actas, Buenos Aires, pp. $1-61$.

Urien, C.M., Zambrano, J.J., 1994. Petroleum systems in the Neuquén Basin, Argentina. In: In: Dow, W.G., Magoon, L.B. (Eds.), The Petroleum System: from Source to Trap, vol. 60. AAPG Memoirs, pp. 513-534.

Veiga, G.D., Spalletti, L.A., Schwarz, E., 2011. Los depósitos continentales del Miembro Avilé de la Formación Agrio (Hauteriviano). In: Leanza, H.A., Arregui, C., Carbone, O., Danieli, J.C., Vallés, J. (Eds.), Relatorio Geología y Recursos Naturales de la provincia del Neuquén. Asociación Geológica Argentina, Buenos Aires, pp. 171-173.

Vergani, G.D., Tankard, A.J., Belotti, H.J., Welsink, H.J., 1995. Tectonic evolution and paleogeography of the Neuquén Basin, Argentina: petroleum basins of south America. AAPG (Am. Assoc. Pet. Geol.) Bull. 62, 383-402.

Ver Straeten, C.A., Brett, C.E., Sageman, B.B., 2011. Mudrock sequence stratigraphy: a multi-proxy (sedimentological, paleobiological and geochemical) approach, Devonian Appalachian Basin. Palaeogeogr. Palaeoclimatol. Palaeoecol. 304, 54-73.

Villar, H.J., Laffitte, G.A., Legarreta, L., 1998. The source rocks of the Mesozoic Petroleum Systems of Argentina: a comparative overview on their geochemistry, paleoenvironments and hydrocarbon generation patterns. Am. Assoc. Petrol. Geol. Int. Conf. Exhib. 186-187 Abstracts, (Río de Janeiro).

Villar, H.J., Legarreta, L., Cruz, C.E., Laffitte, G.A., Vergani, G., 2005. Los cinco sistemas petroleros coexistentes en el sector sudeste de la cuenca Neuquina: definición geoquímica y comparación a lo largo de una transecta de 150 km. Boletín de Informaciones Petroleras. Cuarta época 3, 50-67.

Volkheimer, W., Melendi, D.L., 1976. Palinomorfos como fósiles guía ( $3^{\circ}$ parte). Técnicas del laboratorio palinológico. Rev. Minera, Geol. Mineral. 34 (1-2), 19-30.

Watkins, D.K., Cooper, M.J., Wilson, P.A., 2005. Calcareous nannoplankton response to Late Albian oceanic anoxic event 1d in the western North Atlantic. Paleoceanography 20, PA2010. https://doi.org/10.1029/2004PA001097.

Weaver, C.E., 1931. Paleontology of the Jurassic and Cretaceous of West Central Argentina, vol. 1 University of Washington Press, Seattle, Washington.

Yrigoyen, M.R., 1991. Hydrocarbon resources of Argentina. Petrotecnia 13, 38-54.

Zeller, M., Verwer, K., Eberli, G.P., Massaferro, J.L., Schwarz, E., Spalletti, L., 2015. Depositional controls on mixed carbonate-siliciclastic cycles and sequences on gently inclined shelf profiles. Sedimnetology 62, 2009-2037. 